WATER, ICE, AND METEOROLOGICAL MEASUREMENTS AT SOUTH CASCADE GLACIER, WASHINGTON, 1995 BALANCE YEAR

U.S. GEOLOGICAL SURVEY

Water-Resources Investigations Report 96-4174

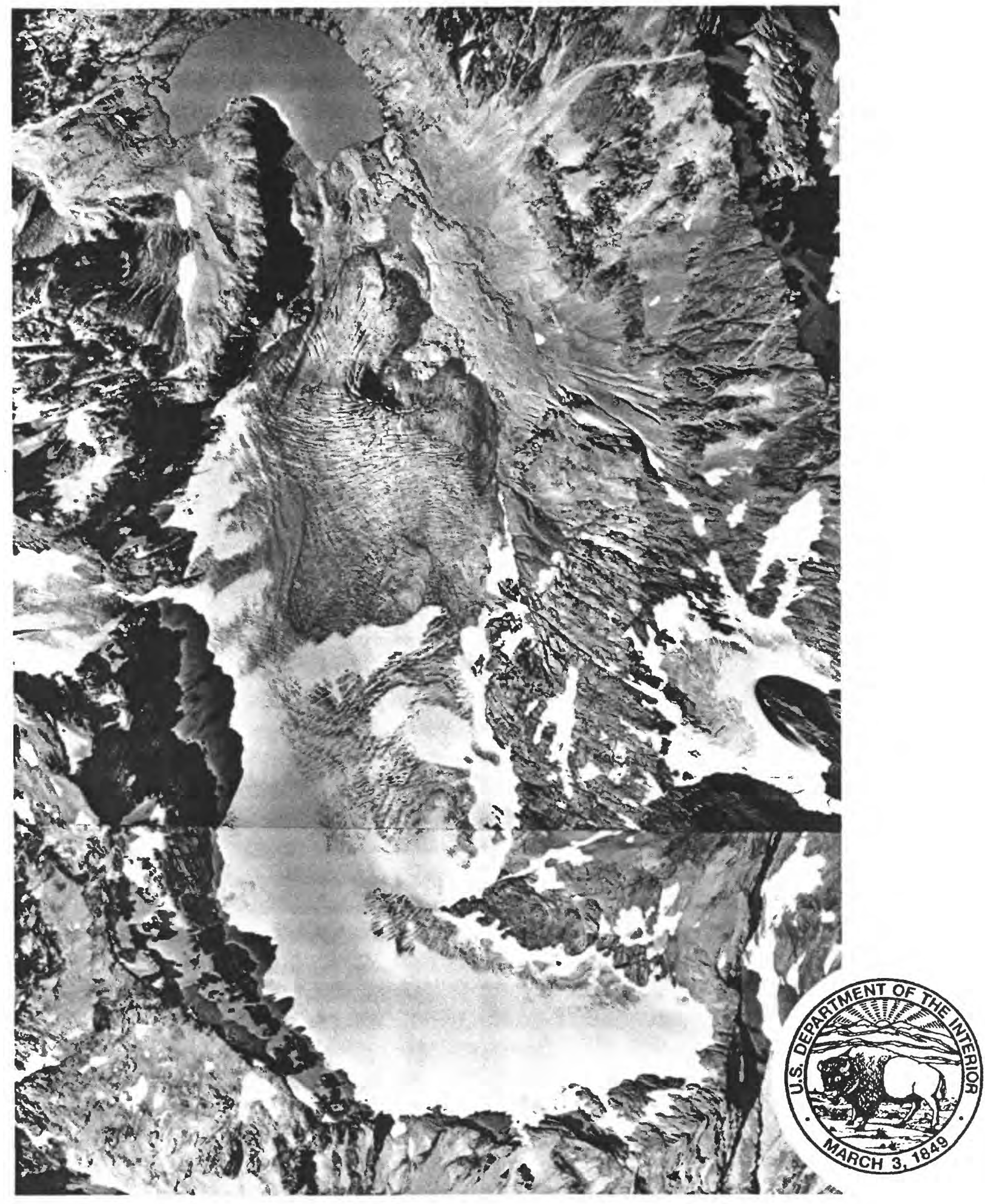




\section{U.S. DEPARTMENT OF THE INTERIOR \\ BRUCE BABBITT, Secretary \\ U.S. GEOLOGICAL SURVEY \\ Gordon P. Eaton, Director}

For additional information write to:

Ice and Climate Project

U.S. Geological Survey

University of Puget Sound

Tacoma, Washington 98416
Copies of this report can

be purchased from:

U.S. Geological Survey

Branch of Information Services

Box 25286

Denver Federal Center

Denver, Colorado 80225 



\section{CONTENTS}

Abstract

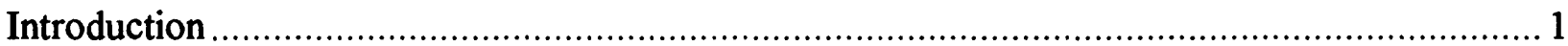

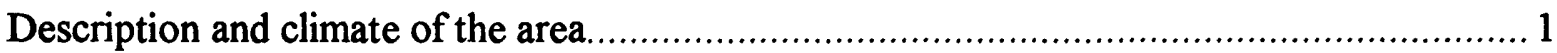

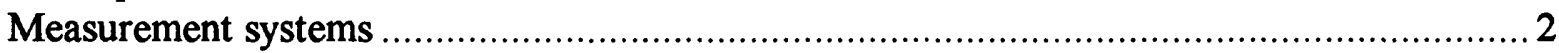

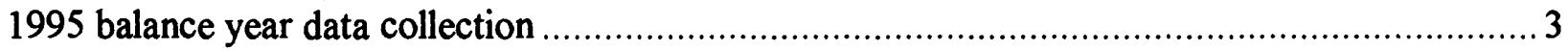

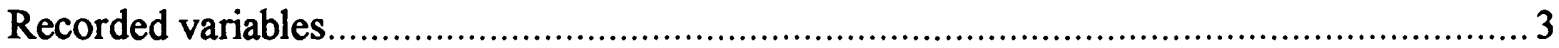

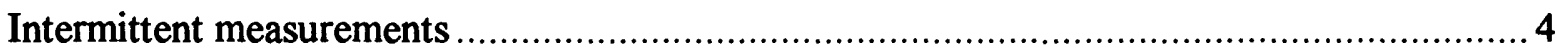

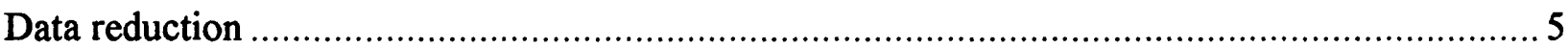

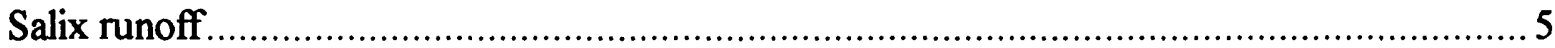

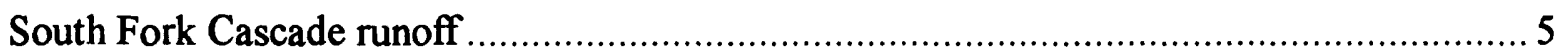

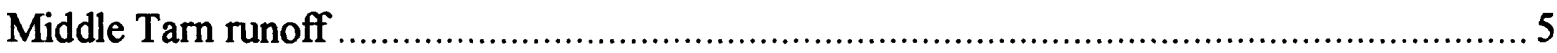

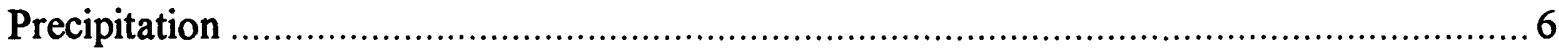

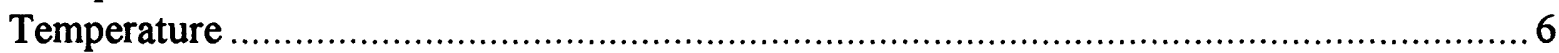

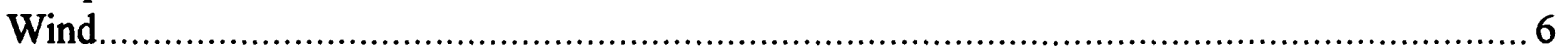

Mass balance

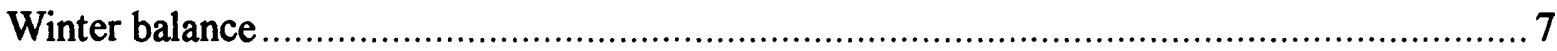

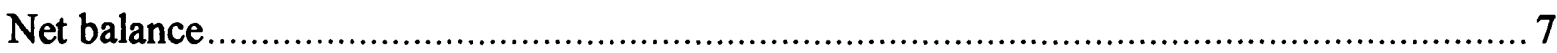

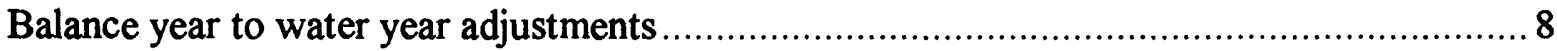

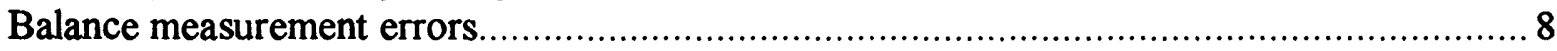

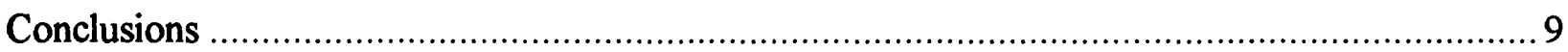

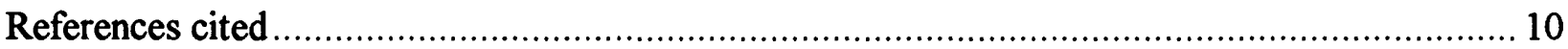

\section{ILLUSTRATIONS}

Figure 1. Map showing South Cascade Glacier and vicinity................................................ 11

2. Graph showing air temperature and solar radiation near South Cascade

Glacier during the 1995 water year ........................................................... 12

3. Graph showing river stage and barometric pressure near South Cascade

Glacier during the 1995 water year .............................................................. 13

4. Graphs showing wind speed and direction at Middle Tarn, during the

four quarters of the 1995 water year ............................................................. 14

5. Map showing snow depths on South Cascade Glacier on May 15-16, 1995 ............. 15

6. Graph showing snow depth and firn or ice loss at South Cascade Glacier

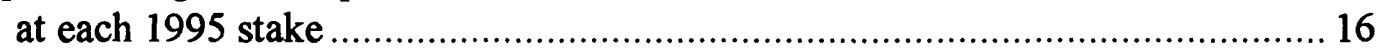

7. Vertical photograph of South Cascade Glacier, September 12, 1995 ...................... 17

8. Map showing altitude grid for South Cascade Glacier,

September 12, 1995

9. Map showing South Cascade Glacier terminus positions,

September 6, 1994 and September 12, 1995

10. Graphs showing runoff and precipitation near South Cascade Glacier

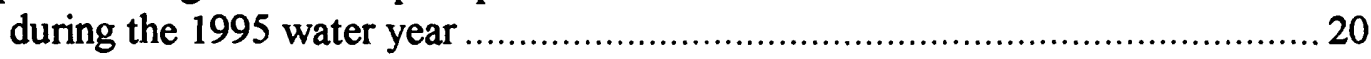

11. Graph showing Middle Tarn and Salix precipitation for 1995 water year ................. 21

12. Graphs showing correlation of air temperatures near South Cascade

Glacier. 


\section{ILLUSTRATIONS--Continued}

13. Graphs showing wind direction and speed at Middle Tarn during the

1995 water year.

14. Graph showing snow density as a function of altitude at South Cascade

Glacier, May 15-16, 1995.

15. Graph showing snow depth as a function of altitude at South Cascade

Glacier, May 15-16, 1995

16. Graph showing net balance as a function of altitude at South Cascade

Glacier, 1995

17. Graph showing winter, summer, and net mass balances for South

Cascade Glacier, 1953-95

TABLES

Table 1. Air temperature at 1,587 meters altitude, Salix Basin, 1995 water year. 25

2. Air temperature at 1,615 meters altitude, South Cascade Glacier Basin, 1995 water year

3. Air temperature at 1,631 meters altitude, South Cascade Glacier Basin, 1995 water year

4. Air temperature at 1,848 meters altitude, South Cascade Glacier Basin, 1995 water year.

5. Precipitation at 1,587 meters altitude, Salix Basin, 1995 water year

6. Precipitation at 1,631 meters altitude, Middle Tarn, 1995 water year 29

7. Short-wave solar radiation at 1,848 meters altitude, South Cascade Glacier Basin, 1995 water year.

8. Wind speed at 1,631 meters altitude, South Cascade Glacier Basin, 1995 water year 30

9. Snow depths at South Cascade Glacier, May 15-16, 1995 31

10. Snow density near the South Fork Cascade gaging station, at 1,618 meters altitude, May 16, 1995 .

11. Snow density on South Cascade Glacier, at 1,844 meters altitude, May 15-16, 1995

12. Stake measurements at South Cascade Glacier in the 1995 balance year .................. 32

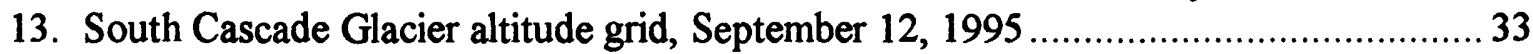

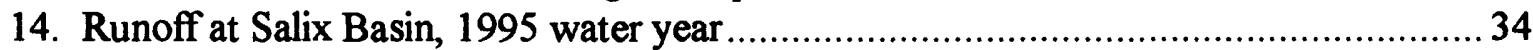

15. Runoff at South Cascade Glacier Basin, 1995 water year............................................. 34

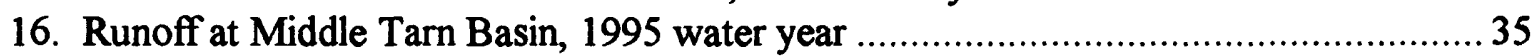

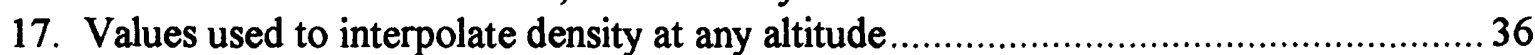

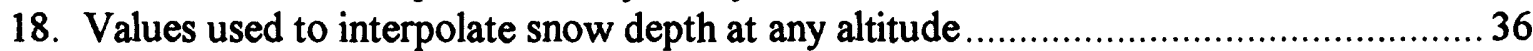

19. Net balance at specific locations on South Cascade Glacier ...................................... 37

20. Values used to interpolate net balance at any altitude................................................ 37 
CONVERSION FACTORS, VERTICAL DATUM, SYMBOLS, AND MACHINE-READABLE FILES

\begin{tabular}{lcl} 
Multiply & By & To obtain \\
\hline degree Celsius $\left({ }^{\circ} \mathrm{C}\right)$ & 1.8, then add 32 & degree Fahrenheit \\
gram $(\mathrm{gm})$ & 0.03215 & ounces (troy) \\
kilogram $(\mathrm{kg})$ & 2.205 & pound \\
kilometer $(\mathrm{km})$ & 0.6214 & mile \\
kilometer per hour $(\mathrm{km} / \mathrm{h})$ & 0.6214 & mile per hour \\
kilopascal $(\mathrm{kPa})$ & 0.1450 & pound per square inch \\
meter $(\mathrm{m})$ & 3.281 & foot \\
millimeter $(\mathrm{mm})$ & 0.03937 & inch \\
square kilometer $\left(\mathrm{km}^{2}\right)$ & 0.3861 & square mile \\
watt per meter squared $\left(\mathrm{w} / \mathrm{m}^{2}\right)$ & 0.001435 & calorie \\
\hline
\end{tabular}

\section{Vertical datum:}

In this report "sea level" refers to the National Geodetic Vertical Datum of 1929 (NGVD of 1929)--a geodetic datum derived from a general adjustment of the first-order level nets of both the United States and Canada, formerly called Sea Level Datum of 1929.

Symbols used in this report:

$\bar{b}_{0} \quad$ The change in balance between the minimum balance near the beginning of the water year and October 1 .

$\bar{b}_{1} \quad$ The change in balance between the minimum balance near the end of the water year and September 30.

$\bar{b}_{\mathrm{a}} \quad$ The change in snow, firn, and ice storage between the beginning and end of some fixed period, which here is the water year.

$\bar{b}_{\mathrm{m}}(\mathrm{s}) \quad$ The snow above the previously formed summer surface as measured directly by field work in late spring as near as possible to the time of greatest glacier mass.

$\bar{b}_{\mathrm{n}} \quad$ The change in snow, firn, and ice storage between times of minimum mass.

$\bar{b}_{\mathrm{w}}$ (s) The maximum of snow mass during the balance year.

q River discharge.

$\mathrm{S} \quad$ River stage.

$\mathrm{X} \quad$ Approximate east/west position in the local survey net.

Y Approximate north/south position in the local survey net.

Z Altitude above sea level.

Machine-readable files:

Most of the data contained in this report have been recorded on easily copied computer media. This machine-readable material is available from the World Data Center, Campus Box 449, University of Colorado, Boulder, CO 80309. 


\title{
WATER, ICE, AND METEOROLOGICAL MEASUREMENTS AT SOUTH CASCADE GLACIER, WASHINGTON, 1995 BALANCE YEAR
}

\author{
Robert M. Krimmel
}

\begin{abstract}
Winter snow accumulation and summer snow, firn, and ice melt were measured at South Cascade Glacier, Washington to determine the winter and net balances for the 1995 balance year. The 1995 winter balance, averaged over the glacier, was 2.86 meters, and the net balance was -0.69 meter. The winter balance was approximately 0.5 meter greater than the 1977-94 average winter balance. The net balance was approximately 0.3 meter less negative than the 1977-94 average net balance. Runoff was measured from the glacier and an adjacent nonglacierized basin. Air temperature, precipitation, barometric pressure, solar radiation, and wind speed were measured adjacent to the glacier. This report makes these data available to the glaciological and climatological community.
\end{abstract}

\section{INTRODUCTION}

South Cascade Glacier is a small valley glacier near the crest of the North Cascade Range, Washington State (fig. 1). Numerous variables relating to the glacier regime have been measured on and near South Cascade Glacier since the late 1950's. The long-term goal of this project is to understand the climate-glacier relation. A short-term goal is to document the measurements with sufficient detail so that an internally consistent record of conditions on and around the glacier can be assembled despite personnel changes, discontinuous records, and changing methods of data collection and analysis. Some periods of record at South Cascade Glacier have been documented. Work from 1957-64 is described by Meier and Tangborn (1965), work from 1965-67 is described by Meier and others (1971) and by Tangborn and others (1977). Hydrologic and meteorological data for 1957-67 are presented by Sullivan (1994). Mass balance results for 1958-85 are summarized by Krimmel (1989), and are presented in detail for 1992-94 (Krimmel, 1993, 1994, 1995). The purpose of this report is to document the measurements of the 1995 balance year that are relevant to the relation between South Cascade Glacier and climate. These measurements include those of basin runoff, precipitation, solar radiation, wind speed and direction, air temperature, snow thickness and density, ice ablation, and surface altitude.

\section{Description and Climate of the Area}

South Cascade Glacier (fig. 1) is located at the head of the South Fork of the Cascade River, a tributary to the Skagit River, which flows into Puget Sound about $100 \mathrm{~km}$ to the west. The region is dominated by steep terrain, with relief of more than $1,000 \mathrm{~m}$. Areas within the basin not covered by glacier ice or water are underlain by bedrock. The bedrock is mantled either by a thin layer of soil or, in places, by scrub conifer, heather, or other vegetation typical of the high North Cascade Range, or is covered by glacial moraine or outwash material. 
South Cascade Lake Basin has an area ${ }^{1}$ of $6.14 \mathrm{~km}^{2}$, and spans from 1,615 to $2,518 \mathrm{~m}$ altitude. A sub-basin of the South Cascade Lake Basin is the $4.46-\mathrm{km}^{2}$ Middle Tarn Basin ${ }^{2}$, which constitutes the southern two-thirds of the South Cascade Lake Basin (fig. 1). Virtually all icemelt $^{3}$ within the South Cascade Lake Basin takes place in the Middle Tarn Basin.

Salix Basin (fig. 1) is an unglacierized basin adjacent to the South Cascade Lake Basin. It has an area ${ }^{4}$ of $0.22 \mathrm{~km}^{2}$, spans from 1,587 to $2,140 \mathrm{~m}$ altitude, and is predominantly south facing. Data from Salix Basin are included in the report so that differences between this nonglacierized basin and the adjacent glacierized basin can be seen.

The climate of the region is maritime. Near the glacier, typical winter low temperatures are about $-10^{\circ} \mathrm{C}$, and typical summer high temperatures are about $20^{\circ} \mathrm{C}$. Most of the precipitation, which commonly reaches $4.5 \mathrm{~m}$ annually (Meier and others, 1971), falls as snow in the period October to May.

\section{Measurement Systems}

Glacier mass balance definitions (Mayo and others, 1972) are adhered to in this report, and the stratigraphic system, which is more field compatible than the fixed date system, is usually used. The specific terms are defined where first used. Other mass balance nomenclatures are in use, notably those described by Østrem and Brugman (1991), which could as well be used to report these results. The definitions by Mayo and others (1972) are used to maintain consistency with earlier reports on South Cascade Glacier work.

The balance year, defined by Mayo and others (1972) as the interval between the minimum glacier mass in one year and the minimum glacier mass the following year, is used when appropriate. The water year (WY) is the interval between October 1 of one year and September 30 of the following year; it is designated by the calendar year in which it ends.

All local geodetic coordinates are in meters, in which the local $+Y$ axis is approximately true north. Vertical locations are in meters above the National Geodetic Vertical Datum of 1929. Horizontal locations are defined by a local system that can be converted to Universal Transverse Mercator (UTM) zone 10 coordinates by:

$$
\begin{aligned}
& \text { UTM easting }=\text { local X }(0.99985)+642,000 \\
& \text { UTM northing }=\text { local Y }(0.99985)+5,355,000 .
\end{aligned}
$$

Densities are given as a decimal fraction of the density of water, the density of which is considered to be 1,000 kilograms per cubic meter.

\footnotetext{
${ }^{1}$ The area of this basin has been previously reported as 6.02 and $6.11 \mathrm{~km}^{2}$. These differences are due to different interpretations of the drainage divide.

2 "Middle Tarn" is an unofficial name.

${ }^{3}$ A small, debris-covered area of perennial ice lies outside of the Middle Tarn Basin.

${ }^{4}$ Salix Basin drainage divides are poorly defined.
} 


\section{BALANCE YEAR DATA COLLECTION}

\section{Recorded Variables}

Several variables are measured continuously: in this report, the records of these variables are truncated to the water year, October 1, 1994 through September 30, 1995. When information concerning these variables is required, but is outside of the WY, the required data are discussed. The continuous measurements may be stored on analog recorders, which give a continuous trace of the variable; on digital recorders, which store either instantaneous values, or for some variables a value that is averaged over some time interval; or are transmitted to Tacoma, Washington with a satellite link using a data collection platform (DCP) near the sensors. Some variables are stored simultaneously on both analog and digital recorders.

Air temperature was measured at the Salix gaging station with a DCP, at the South Fork gaging station with both a DCP and an analog strip chart recorder, at the Middle Tarn gaging station with a DCP, and at the Hut (fig. 1) with a DCP. Each of these records is shown graphically (fig. 2). Temperature was measured instantaneously once per hour at each station. Temperature is estimated to be accurate to $\pm 1^{\circ} \mathrm{C}$. During times when the South Fork gaging station DCP was not functional, the daily average temperature was taken from the analog strip chart at the same location: it is estimated to be accurate to $\pm 2^{\circ} \mathrm{C}$ and is shown as a dot on figure 2. Daily maximum (highest of the hourly readings), minimum (lowest of the 24 hourly readings), and mean temperatures are given in tables 1-4.

Precipitation was measured at Salix and Middle Tarn gaging stations. The tipping bucket gage catch was accumulated for 1 hour and recorded with a DCP. Both gage orifices were 200 $\mathrm{mm}$ in diameter and neither had wind screens. The precipitation gages are sensitive to $0.024 \mathrm{~mm}$ increments of precipitation. Precipitation is known to vary significantly over a short distance, especially in areas of high relief. Wind is also known to influence the catch of precipitation gages. These gages were in operation intermittently over the entire year, but no attempt was made to heat the orifices so that snow would pass to the tipping buckets. No attempt has been made to correct the measured precipitation for any of these influences. Daily total precipitation gage catch is given in tables 5 and 6.

Incident short-wave solar radiation was measured at the Hut (fig. 2 and table 7) and is estimated to be accurate to $\pm 100 \mathrm{w} / \mathrm{m}^{2}$. The sensor is on an exposed mast, but even so, may collect snow or rime during winter.

Salix Creek stage was recorded on a DCP and an analog strip chart. The recorders share a single float-driven stage sensor. South Fork Cascade River stage was digitally recorded, and recorded on an analog strip chart. Each recorder had independent float-driven stage sensors, in independent wells, and are calibrated to each other. Middle Tarn stage was recorded with a DCP and with a digital recorder. The recorders share a single float-driven stage sensor. These stage records are shown in figure 3 . The stage recorders are sensitive to $\pm 3 \mathrm{~mm}$ and are estimated to be accurate to $\pm 3 \mathrm{~mm}$. 
Barometric pressure was recorded with a DCP at the South Fork gaging station and is estimated to be accurate to $\pm 0.1 \mathrm{kPa}$. Pressure is shown in figure 3 .

Wind speed and direction are measured at Middle Tarn gaging station with a DCP. Wind speed is estimated to be accurate to $\pm 5 \mathrm{~km} / \mathrm{h}$, and direction to \pm 5 degrees. Both wind speed and direction are shown in figure 4 , and wind speed is shown in table 8 .

\section{Intermittent Measurements}

Snow depth, density, ice ablation and river discharge measurements are made during site visits several times during the year. Instruments and facilities are serviced during these visits as well.

Snow depth was measured by probing at numerous locations on May 15-16, 1995 (fig. 5, table 9). Snow density was measured with a snow tube along an 8-point snow course near the South Fork gaging station on May 16, 1995 (table 10) and in a snow pit and with a coring auger near P1 (fig. 1) on May 15, 1995 (table 11). The snow density measurements were used to convert the snow depths to snow water equivalent (SWE).

Aluminum stakes with wood bottom plugs, $33 \mathrm{~mm}$ in diameter, were set into firn or ice on May 15-16, 1995 at four locations on the glacier (fig. 1). The level of snow, firn, or ice was recorded on these stakes several times during the year (table 12, fig. 6).

Aerial photography provided a record of the condition of the glacier on September 12, 1995 (fig. 7). Stereo aerial photographs are used to make measurements of the size and shape of the glacier, and location of transient snowlines. A digital altitude model (DEM) of the glacier was formed by photogrammetric measurement of altitude at a regular $100-\mathrm{m}$ spacing over the area of the glacier. The DEM, the altitudes of which are estimated to be accurate to $\pm 1 \mathrm{~m}$, is shown in figure 8 and table 13. The terminus of the glacier (fig. 9) was delineated from the photographs by measuring the locations of numerous points along its edge. The location of the points is estimated to be accurate to $\pm 1 \mathrm{~m}$. The area of the glacier near the end of the 1994 balance year was 2.052 $\mathrm{km}^{2}$ (Krimmel, 1995). Assuming that the area of the glacier south of $Y=3,200 \mathrm{~m}$ is unchanged since 1994, the area of the glacier near the end of the 1995 balance year was $2.034 \mathrm{~km}^{2}$. The endof-year snow- and ice-covered area within the South Cascade Glacier basin was considerably greater in 1995 than in 1994 because more snow remained at the end of the 1995 balance year. The area of this snow cover was not measured, but is readily seen by comparing the vertical photographs of the glacier in the respective years. The transient snowline is clearly visible on the September 12,1995, vertical photography. An estimate was made of the the melt after the date of the photograph to determine the highest altitude the 1995 glacier snowline reached (fig. 1). The average altitude of points spaced at regular intervals along the highest snowline is the equilibrium line altitude, $1,945 \mathrm{~m}$. The ratio of the accumulation area to the total glacier area was 0.23 in 1995. 


\section{DATA REDUCTION}

\section{Salix Runoff}

Salix Creek stage measurements are converted to instantaneous discharge values, which are averaged for each day and converted to a basin-averaged daily runoff (fig. 10, table 14). The rating curve used to convert stage to discharge was the same that has been used since the measurements began in 1960:

$$
\mathrm{q}=\mathrm{S}^{2.57 * 2.71}
$$

where $\mathrm{q}$ is discharge in cubic feet per second and $\mathrm{S}$ is stage in feet. (Equations for the rating curves are given in English units for the convenience of the author and reader, as the original stage data are in feet and the machine-readable files are in feet. Except in these two instances, stage has been converted to meters).

\section{South Fork Cascade Runoff}

South Fork stage measurements are similarly converted to instantaneous discharge values, which are averaged for each day and converted to a basin-averaged daily runoff (fig. 10, table 15). The rating curve used to convert stage to discharge was based on the rating used in 1994, but adjusted slightly using three discharge measurements.

For stage below 0.87 feet:

$$
q=0.0036+5.62 * S-5.57 * S^{2}+14.74 * S^{3}
$$

For stage above 0.86 feet:

$$
q=17.45-43.14 * S+40.94 * S^{2}-0.90 * S^{3}
$$

\section{Middle Tarn Runoff}

Stage measurements were converted to discharge using a rating curve determined from 14 discharge measurements made between September 8, 1992 and September 16, 1994. The outlet from Middle Tarn is a bedrock channel that does not change; therefore, the rating curve is expected to remain stable at Middle Tarn. For a stage above 0.35 feet,

$$
q=2.064-3.673 * S+24.770 * S^{2},
$$

and at a stage of 0.35 and below,

$$
\mathrm{q}=\mathrm{S}^{1.809 * 25.123 .}
$$

The instantaneous discharge measurements are converted to a basin-averaged daily runoff (fig. 10, table 15). 


\section{Precipitation}

The Salix and Middle Tarn precipitation gages were in operation most of WY 1995. Incremental precipitation was accumulated for each day, and the daily total precipitation is shown graphically in figure 10 , and in tables 5 and 6.

Middle Tarn and Salix daily total precipitation measurements are cross correlated (R-squared $=0.77$ ) in figure 11 . The cross correlation suggests that it is slightly wetter at Salix than at Middle Tarn, and that precipitation is commonly very different between the two sites. Salix may only appear to be wetter because it is normally warmer at Salix than at Middle Tarn, and rain is more reliably measured than snow. Neither precipitation measurement site is considered to be necessarily representative because of local variations in precipitation, the difficulty of measuring precipitation when it is windy, or when the precipitation occurs as snow. The cross correlation used the 309 days on which both gages were in operation.

\section{Temperature}

The most complete air temperature record, both in 1995 and for the entire period of record near South Cascade Glacier beginning in the late 1950's, is from the South Fork gaging station. The average daily temperatures at Salix, Middle Tarn, and Hut sensor sites are cross correlated with temperatures at the South Fork gaging station (fig. 12). Temperatures at Salix were generally warmer than those at South Fork, probably because Salix is at a lower altitude and farther from South Cascade Lake. Temperatures at Middle Tarn were generally cooler than at South Fork, probably because it is closer to the glacier. Temperatures at Hut were generally warmer than at South Fork even though it is $233 \mathrm{~m}$ higher than South Fork, possibly because the Hut station is on a ridge crest and not in the path of the local drainage wind that often flows down the glacier. The R-squared (0.87) is much lower for Hut station than for either Salix (0.97) or Middle Tarn (0.98), suggesting that the Hut site is exposed frequently to different air masses than those found locally below the glacier or the valley bottom.

\section{Wind}

Wind speed and direction were measured during most of the 1995 water year at the Middle Tarn gage site. For the entire year ( 8,760 hours), the speed and direction were sampled 7,212 times: at 6,242 of these times, the speed was not zero. Those 6,242 values are plotted (fig. 13A, direction against speed: the most typical wind is about 150 degrees at $15 \mathrm{~km} / \mathrm{h}$. Nearly as typical is a wind of 300 degrees at $20 \mathrm{~km} / \mathrm{h}$. The 150-degree wind is oriented in a down-glacier direction, and results from the typical fair weather wind. The 300-degree wind occurs during times when a more general west wind across the Cascades is channeled by local topography. The most usual wind speed was $14 \mathrm{~km} / \mathrm{h}$ and the most usual direction was 147 degrees (fig. 13B). 


\section{MASS BALANCE}

\section{Winter Balance}

The mass balance was measured on May 15-16, 1995. Snow thickness was probed along the approximate centerline of the glacier; three short additional profiles helped determine lateral variation (fig. 5). The probe locations were estimated in the field by reference to fixed points adjacent to the glacier. Probing was difficult above $1,850 \mathrm{~m}$ altitude, where snow was commonly more than $5.5 \mathrm{~m}$ thick and a thick ice layer was present at about $3 \mathrm{~m}$ below the surface. The summer surface was verified in a core at $1,844 \mathrm{~m}$ altitude. Probes above $1,850 \mathrm{~m}$ altitude that did not penetrate the ice layer near the 3-m depth were disregarded. Below $1,850 \mathrm{~m}$, the entire thickness of the snow was probed with no major resistance. Snowpack density was measured at $1,844 \mathrm{~m}$ altitude in a pit through the upper $2.18 \mathrm{~m}$ of snow, and with a coring auger through the remainder of snow (table 11). Total snow depth was $5.54 \mathrm{~m}$, and bulk density was 0.52 . A second density measurement was made at $1,618 \mathrm{~m}$ altitude, where a single core was taken through the entire snowpack at eight places along a marked snow course. Average snow depth was $1.85 \mathrm{~m}$, and average density was 0.49 (table 10).

In many previous years, the spring bulk snowpack density decreased as altitude increased. On May 15, 1995, the bulk density increased as altitude increased because a lower density upper layer of snow was present over the entire glacier, and that layer had a proportionally greater influence on the bulk density where the total snow thickness was less. The assumption is made that this density gradient was not linear, but rather changed faster at low altitude than at high altitude. Table 17, showing density at specific altitudes, was taken from the assumed curve (fig. 14). Interpolation from this table was used to find a density at every cell of the DEM.

The altitude of each probed snow depth was determined from its location on the 1995 DEM. The altitude and snow depth of each probe were plotted (fig. 15), and a table of values (table 18) was made from a smoothed curve through the points. Interpolation from table 18 was used to determine a snow depth at each grid cell altitude. The snow depth, multiplied by the snow density, is the water equivalent balance at each grid cell, which when summed gives the measured winter balance, $\bar{b}_{\mathrm{m}}(\mathrm{s}), 2.81 \mathrm{~m}$.

By May 15, 1995, the summer season ablation had started. The air temperature at the South Fork gaging station had been above freezing on most days after April 23, 1995, and river stage began its seasonal rise at each of the gaging stations on April 23. The melt between April 23 and May 15 was probably limited to below $1,800 \mathrm{~m}$ altitude. The estimated amount of melt, April 23-May 15, was $0.05 \mathrm{~m}$ averaged over the glacier. The winter balance on April 23 was thus $2.86 \mathrm{~m}$. This adjustment will affect the summer balance, but not the net balance.

\section{Net Balance}

On September 12, 1995, several cores were taken in the accumulation area. These cores penetrated the entire remaining 1995 snow, and were analyzed for snow density and depth. The results from those cores and the stake readings of September 12, 1995, are given in table 19. Ablation occurred after September 12, and measurements to the firn or ice through newly 
accumulated snow on November 15, 1995, after the end of the ablation of the 1995 material, verified the minimum balance at stakes 1-95, 2-95, and 4-95. Those measurements were used to estimate, by interpolation with altitude, the end of season ablation at stake 3-95 and the core sites (C1-C5). Each of these minimum balance values, with its associated altitude, is plotted in figure 16. A hand-drawn line through those values is used to form an interpolation table (table 20), with which balance at every $100 \mathrm{~m}$ grid point is determined, and which, when summed over the glacier, gives a net balance of $-0.69 \mathrm{~m}$.

\section{Balance Year to Water Year Adjustments}

The final balance increment, $\bar{b}_{1}$, for the 1994 balance year was estimated at $-0.10 \mathrm{~m}$ (Krimmel, 1995). This value is the initial balance increment, $\bar{b}_{0}$, of the 1995 balance year.

The last balance measurements of the 1995 balance year were on September 12, 1995. Ablation continued after that visit. The first measurements of the 1996 balance year were on November 15, 1995, after new snow covered the entire glacier. Above-freezing air temperatures at the altitude of the lower glacier in late November may have resulted in minor additional ice melt after November 15, but precipitation during that period was in the form of snow higher on the glacier, which resulted in an increase in balance when averaged over the glacier. Ablation of snow and ice continued over the entire glacier until a storm beginning on September 27, 1995 produced rain on the lower glacier but snow on the upper glacier. It is estimated, on the basis of a subjective analysis of runoff, precipitation, and air temperature records for October, 1995, that the minimum glacier mass at the end of the 1995 balance year occurred on October 14, 1995. On October 15, 1995, precipitation was snow over most of the glacier, after which the glacier mass remained above the October 14, 1995 minimum mass. It is estimated that the glacier-averaged final balance increment, $\bar{b}_{1}$, between October 1, 1995 and October 14, 1995, was $-0.05 \mathrm{~m}$.

The annual balance, $\bar{b}_{\mathrm{a}}$, is defined by Mayo and others (1972) as the change in snow, firn, and ice storage between the beginning and end of a fixed period, which here is the water year. The measured values of $\bar{b}_{0}, \bar{b}_{1}$, and $\bar{b}_{\mathrm{n}}$ at South Cascade Glacier for the 1995 balance year can be used to derive the annual balance, $\bar{b}_{\mathrm{a}}$, where $\bar{b}_{\mathrm{a}}=\bar{b}_{\mathrm{n}}+\bar{b}_{0}-\bar{b}_{1}=-0.84 \mathrm{~m}$.

\section{Balance Measurements Errors}

Errors in glacier balance measurements are difficult to quantify. In prior years of balance measurements at South Cascade Glacier, error values ranging around $0.10 \mathrm{~m}$ were placed on the balance values (Meier and others, 1971). For 1965 and 1966, more information was used to derive the balances than in 1992-95. The availability of less information in 1995 would suggest that greater errors should be assigned to the 1995 balance. This relative paucity of data for 1995 is offset somewhat, however, by the experience gained since the mid-1960's, when 20-30 ablation stakes were used and it was found that spatial variations in balance were similar from year to year (Meier and Tangborn, 1965). The changes in the geometry of the glacier since the mid-1960's, predominately a loss of ice in the lower glacier area, have not changed the general accumulation

of ablation patterns. Estimated errors are $\bar{b}_{\mathrm{m}}(\mathrm{s}), \bar{b}_{\mathrm{w}}(\mathrm{s})$, and $\bar{b}_{\mathrm{n}}, \pm 0.20 \mathrm{~m} ; \bar{b}_{0}$ and $\bar{b}_{1}, \pm 0.05 \mathrm{~m}$; and the calculated error for $\bar{b}_{\mathrm{a}}$ is $\pm 0.21 \mathrm{~m}$. Although other factors that affect the balance, such as 
internal accumulation of ice, superimposed ice, internal melt, and basal melt, are possible, they are not considered in this report. These unknowns are thought to be small and do not change the error estimations of the surface mass balance data.

\section{CONCLUSIONS}

The apparent 1976-77 climate shift evident in many environmental records (Ebbesmeyer and others, 1991) is partially upheld in the 1995 balance of South Cascade Glacier. The 1959-76 winter, net, and summer balance averages were respectively $2.99,-0.09$, and $-3.09 \mathrm{~m}$; and the same 1977-94 averages were $2.34,-1.02$, and $-3.29 \mathrm{~m}$. In 1995, winter, net, and summer balances were $2.86,-0.69$, and $-3.55 \mathrm{~m}$. Thus, the 1995 winter balance was above average considering the post-1976 average, but normal considering the pre-1976 average; the 1995 net balance was approximately mid-way between the pre-and post-1976 average; and the 1995 summer balance was greater in magnitude than either the pre- or post-1976 average (fig. 17). Greater than normal summer melt in 1995 reduced the greater than normal winter accumulation to a near normal post-1976 average 1995 net balance. 


\section{REFERENCES CITED}

Ebbesmeyer, C.C., Cayan, D.R., McLain, D.R., Nichols, F.H., Peterson, D.H., and Redmond, K.T., 1991, 1976 step in the Pacific climate: Forty environmental changes between 19681975 and 1977-1984, in Betancourt, J.L., and Tharp, V.L., eds., Proceedings of the Seventh Annual Pacific Climate (PACLIM) Workshop, April 1990: California Department of Water Resources, Interagency Ecological Studies Program Technical Report 26, p. 129-141.

Krimmel, R.M., 1989, Mass balance and volume of South Cascade Glacier, Washington, 1958-1985, in Oerlemans, J., ed., Glacier fluctuations and climatic change: Dordrecht, Netherlands, Kluwer Academic Publishers, p. 193-206.

1993, Mass balance, meteorological, and runoff measurements at South Cascade Glacier, Washington, 1992 balance year: U.S. Geological Survey Open-File Report 93-640, 38 p.

1994, Runoff, precipitation, mass balance, and ice velocity measurements at South Cascade Glacier, Washington, 1993 balance year: U.S. Geological Survey Water-Resources Investigations Report 94-4139, 35 p.

1995, Water, ice, and meteorological measurements at South Cascade Glacier, Washington, 1994 balance year: U.S. Geological Survey Water-Resources Investigations Report 95-4162, $41 \mathrm{p}$.

Mayo, L.R., Meier, M.F., and Tangborn, W.V., 1972, A system to combine stratigraphic and annual mass-balance systems--A contribution to the International Hydrological Decade: Journal of Glaciology, v. 11, no. 61, p. 3-14.

Meier, M.F., and Tangborn, W.V., 1965, Net budget and flow of South Cascade Glacier, Washington: Journal of Glaciology, v. 5, no. 41, p. 547-566.

Meier, M.F., Tangborn, W.V., Mayo, L.R., and Post, Austin, 1971, Combined ice and water balances of Gulkana and Wolverine Glaciers, Alaska, and South Cascade Glacier, Washington, 1965 and 1966 water years: U.S. Geological Survey Professional Paper 715-A, $23 \mathrm{p}$.

Østrem, G., and Brugman, M., 1991, Glacier mass-balance measurements--A manual for field and office work: Environment Canada, National Hydrology Research Institute Science Report No. 4,224 p.

Sullivan, M.E., 1994, South Cascade Glacier, Washington--Hydrologic and meteorological data, 1957-67: U.S. Geological Survey Open-File Report 94-77, 105 p.

Tangborn, W.V., Mayo, L.R., Scully, D.R., and Krimmel, R.M., 1977, Combined ice and water balances of Maclure Glacier, California, South Cascade Glacier, Washington, and Wolverine and Gulkana Glaciers, Alaska, 1967 water year: U.S. Geological Survey Professional Paper 715-B, $20 \mathrm{p}$. 


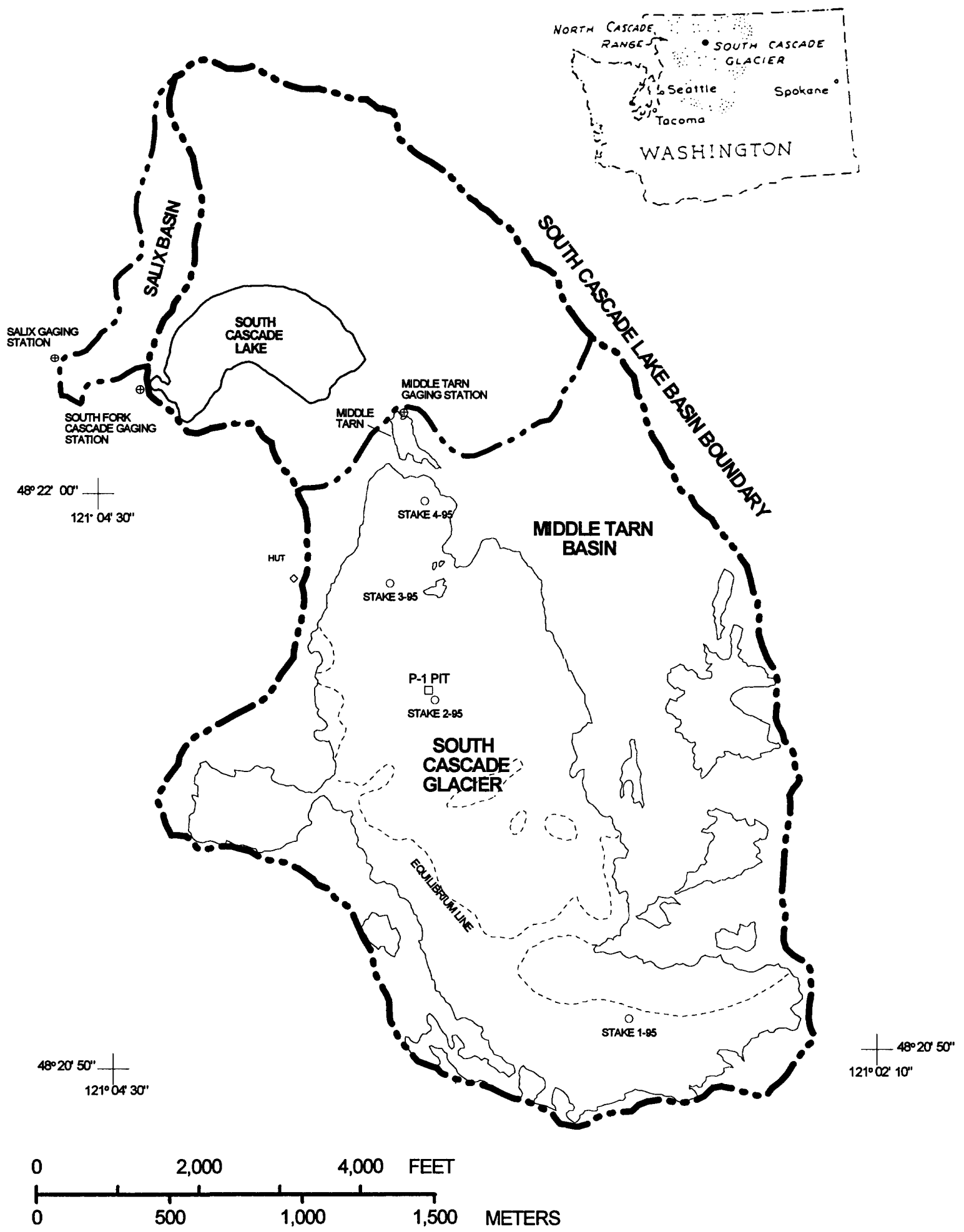

FIGURE 1. South Cascade Glacier and vicinity. 


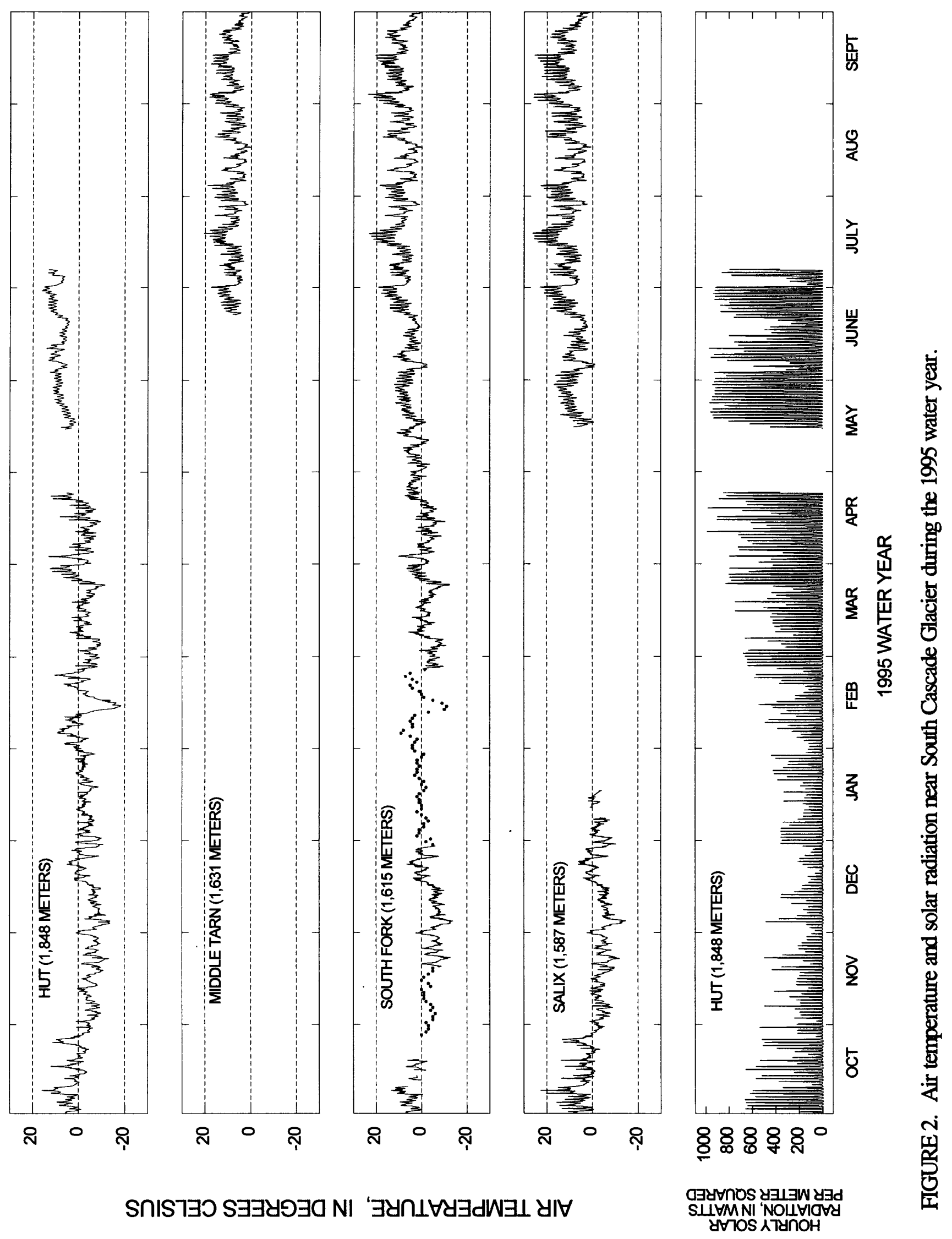



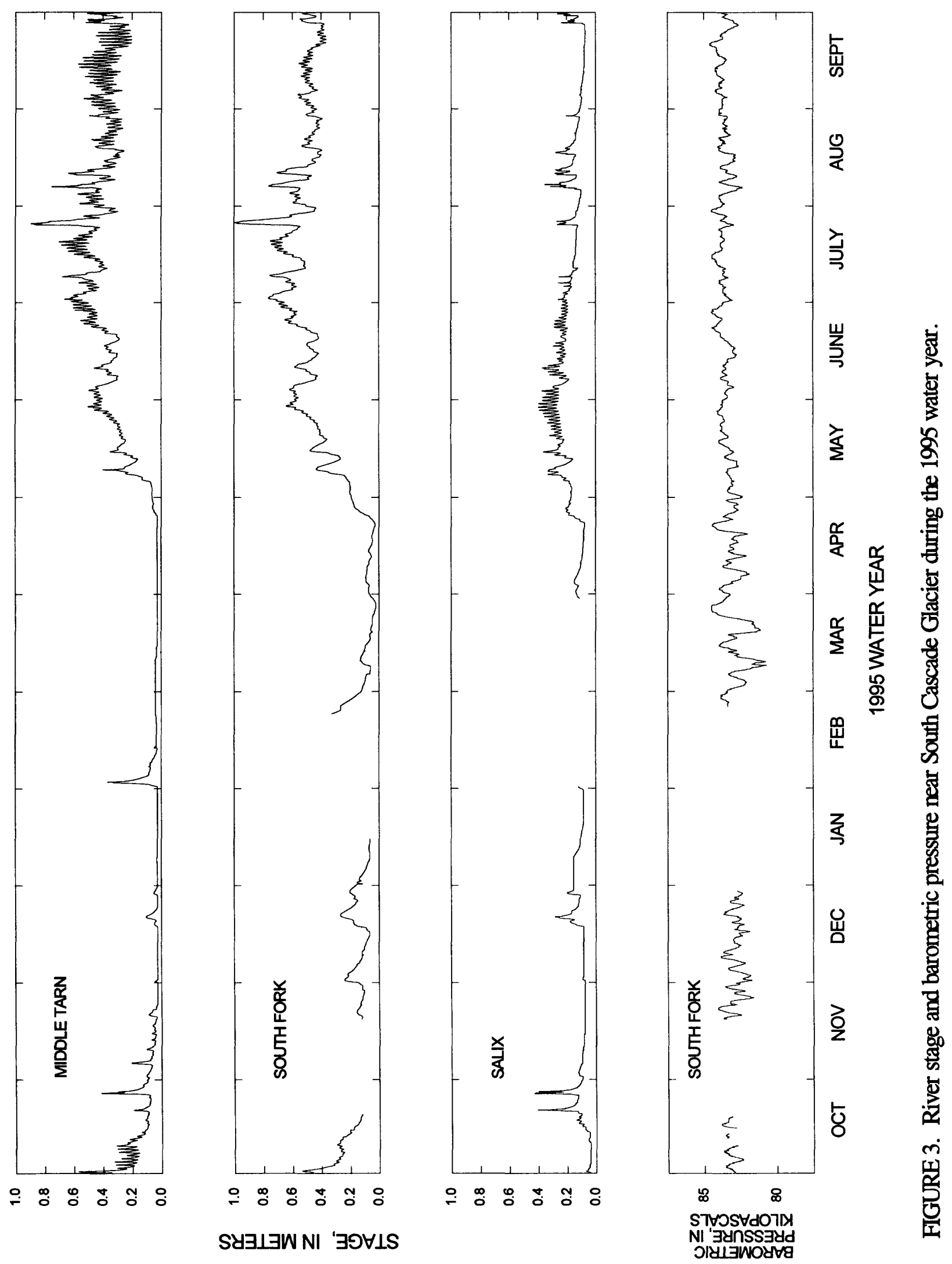

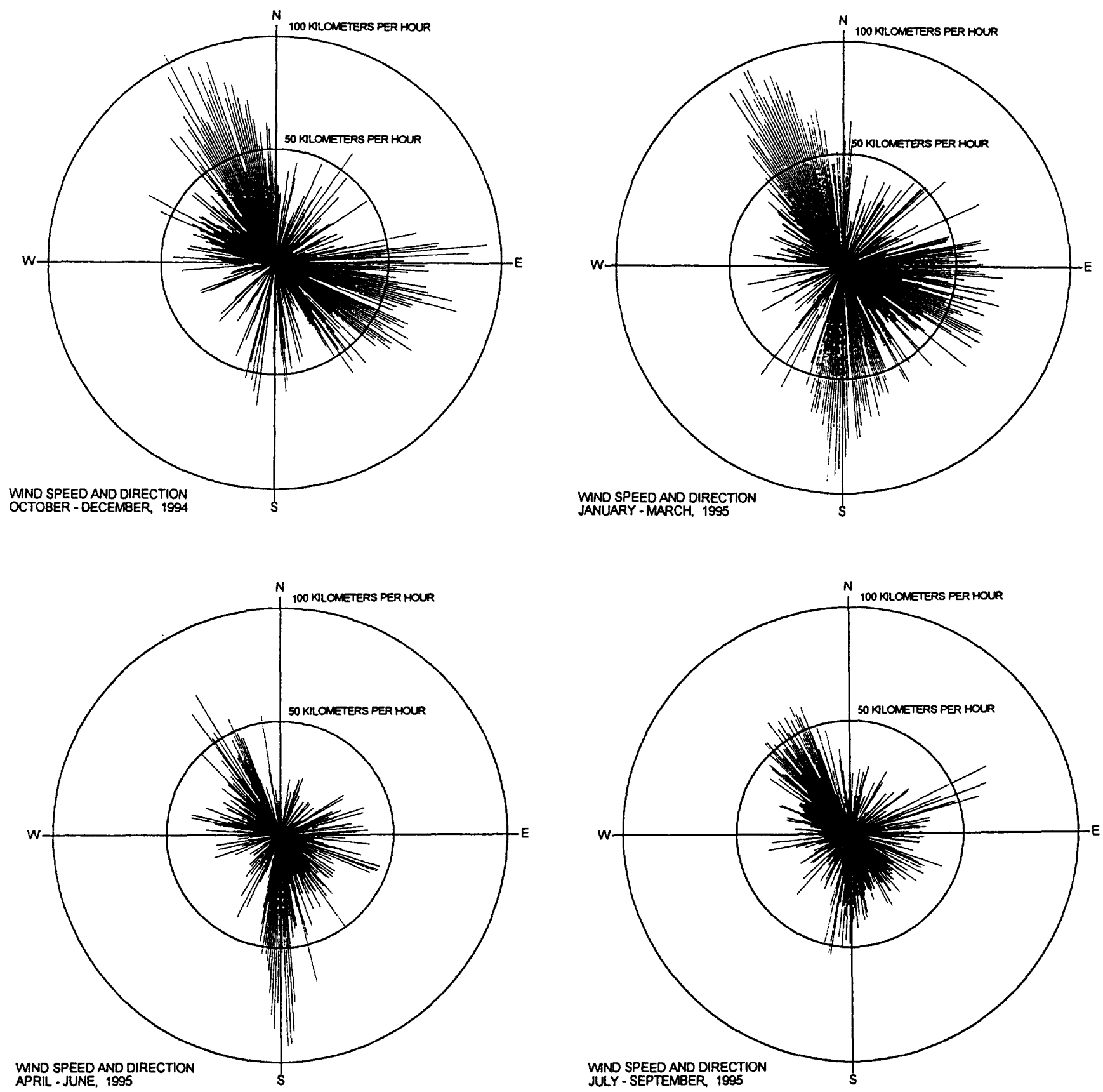

FIGURE 4. Wind speed and direction at Middle Tarn, near South Cascade Glacier, during the four quarters of the 1995 water year. 


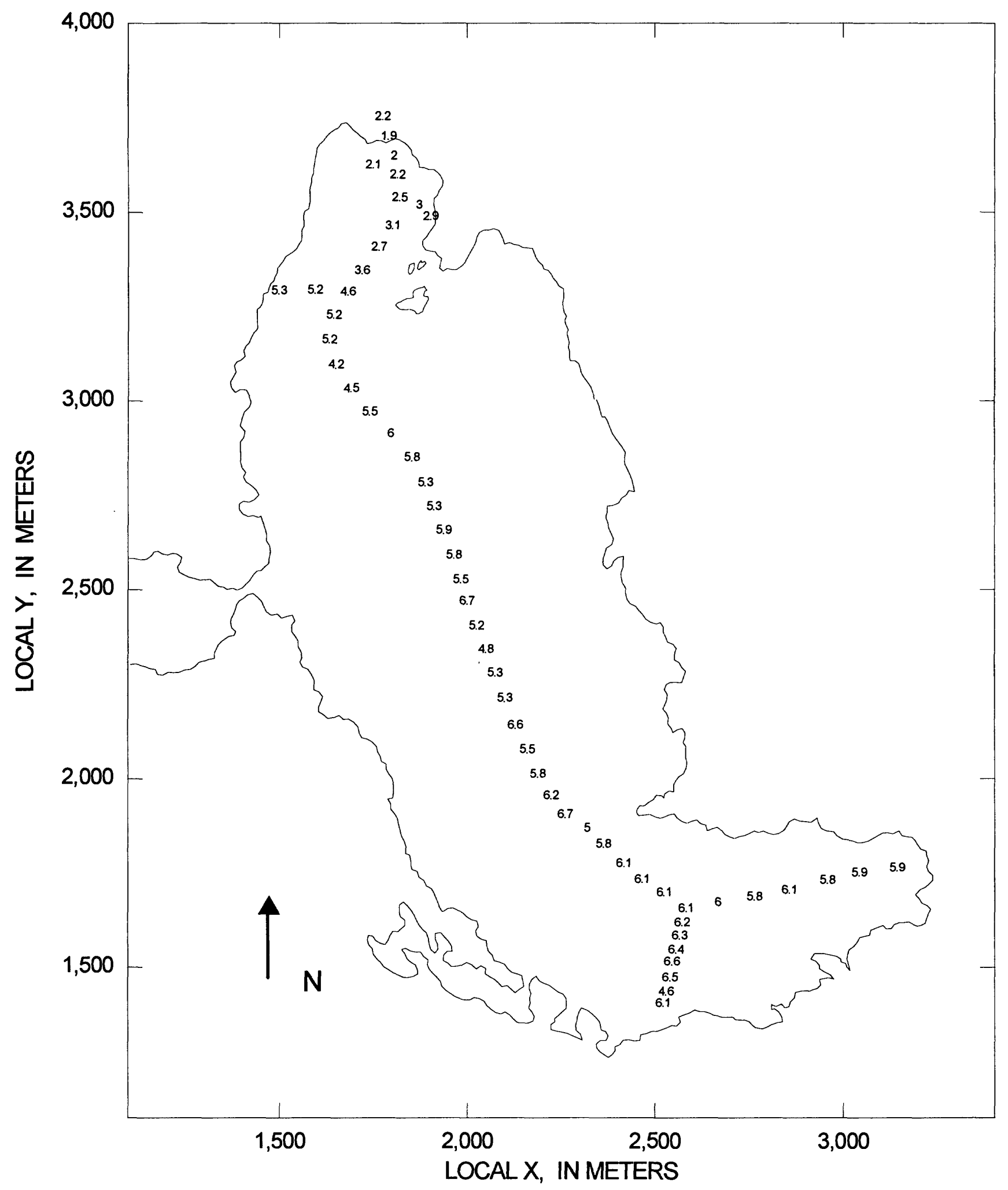

FIGURE 5. Snow depths, in meters, on South Cascade Glacier on May 15-16, 1995. 


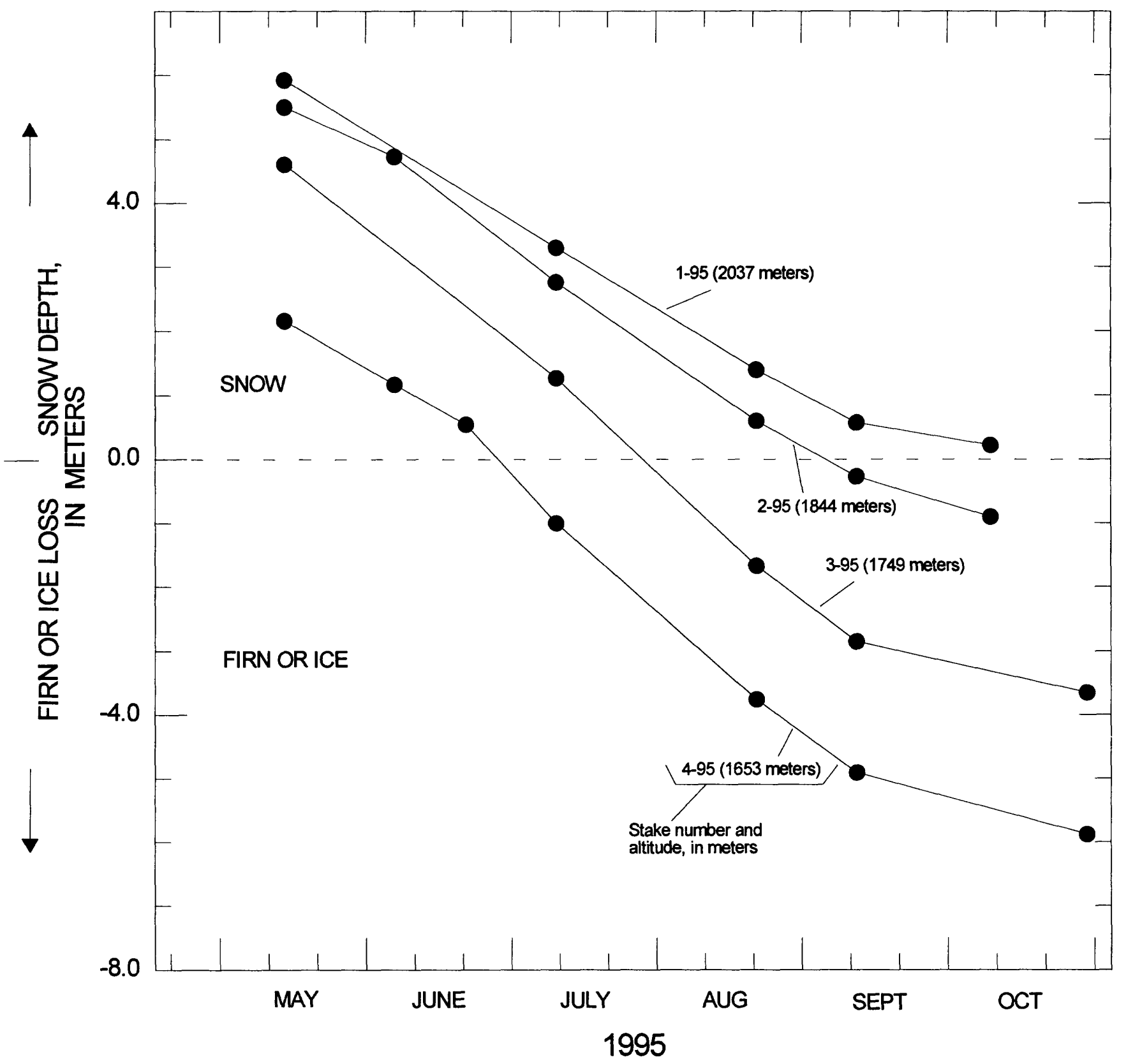

FIGURE 6. Snow depth and firn or ice loss at South Cascade Glacier at each 1995 stake. Depths are accurate to 0.1 meter. (Stake locations shown on figure 1.) 


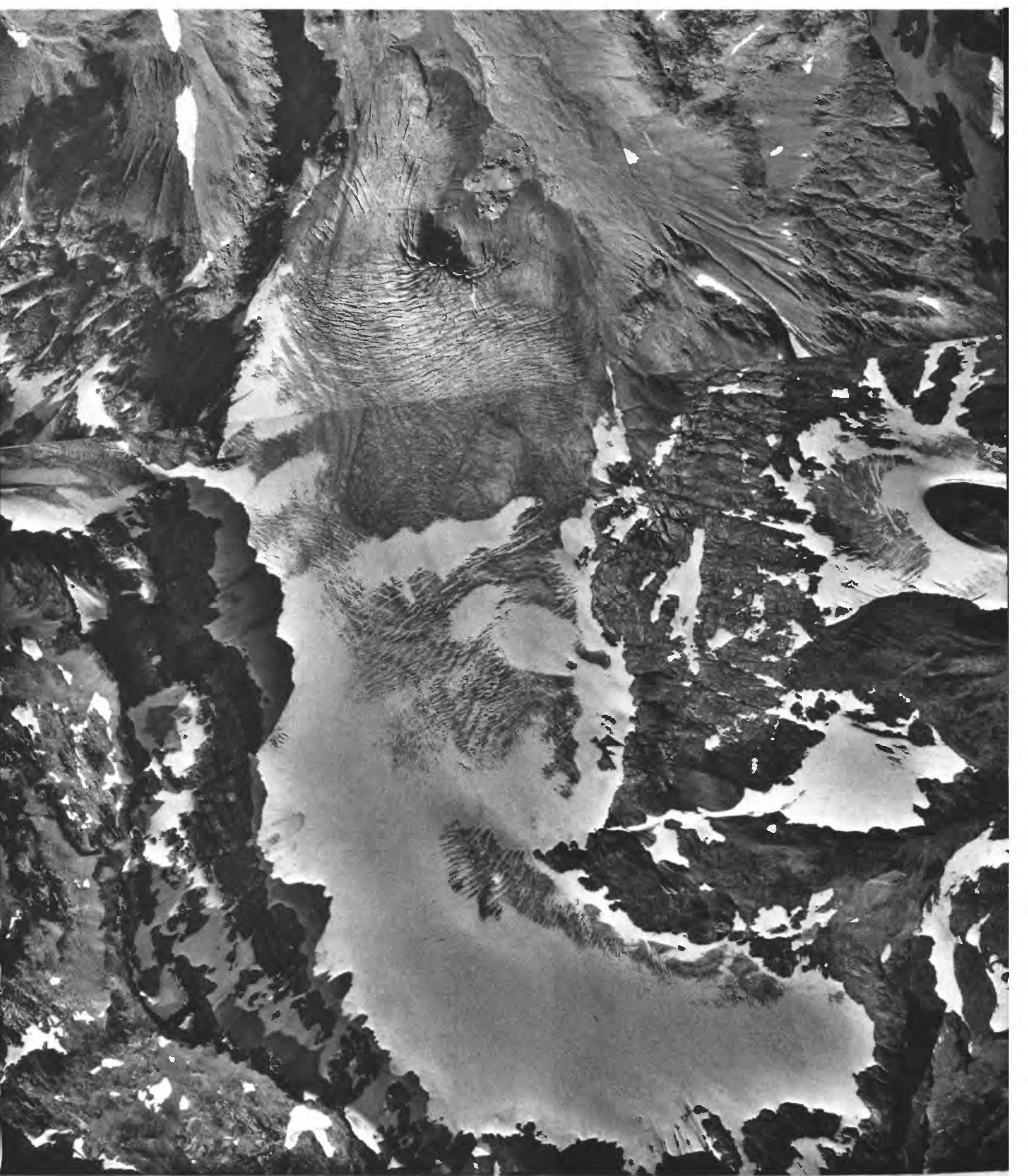

FIGURE 7. Vertical photograph of South Cascade Glacier, September 12, 1995. The maximum width of the glacier is about 1 kilometer, north is approximately up. Mosaic of photographs 95V2-333 and 334. 


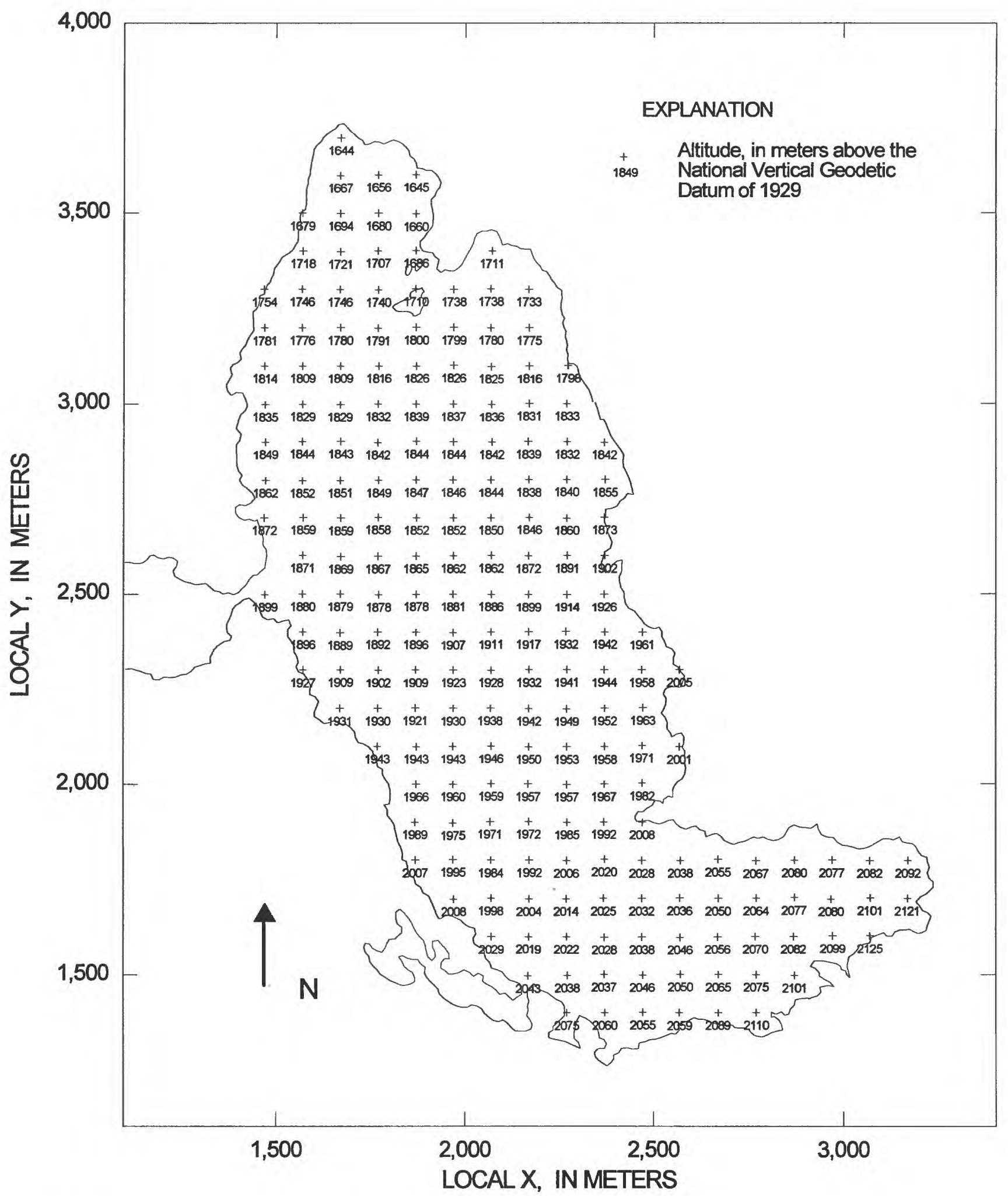

FIGURE 8. Altitude grid for South Cascade Glacier, measured from stereo vertical photographs taken on September 12, 1995. 


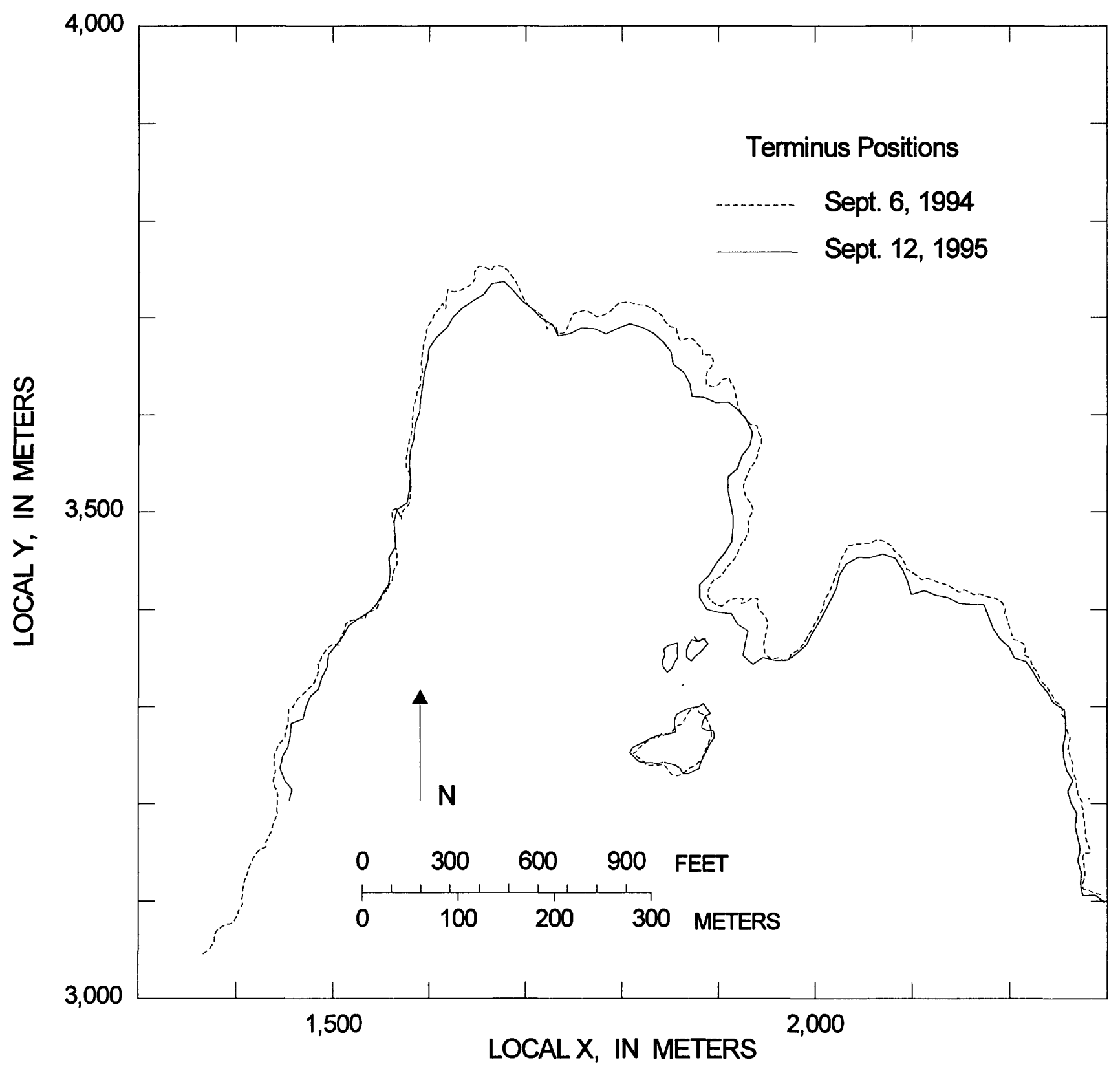

FIGURE 9. South Cascade Glacier terminus positions for September 6, 1994 and September 12, 1995. 

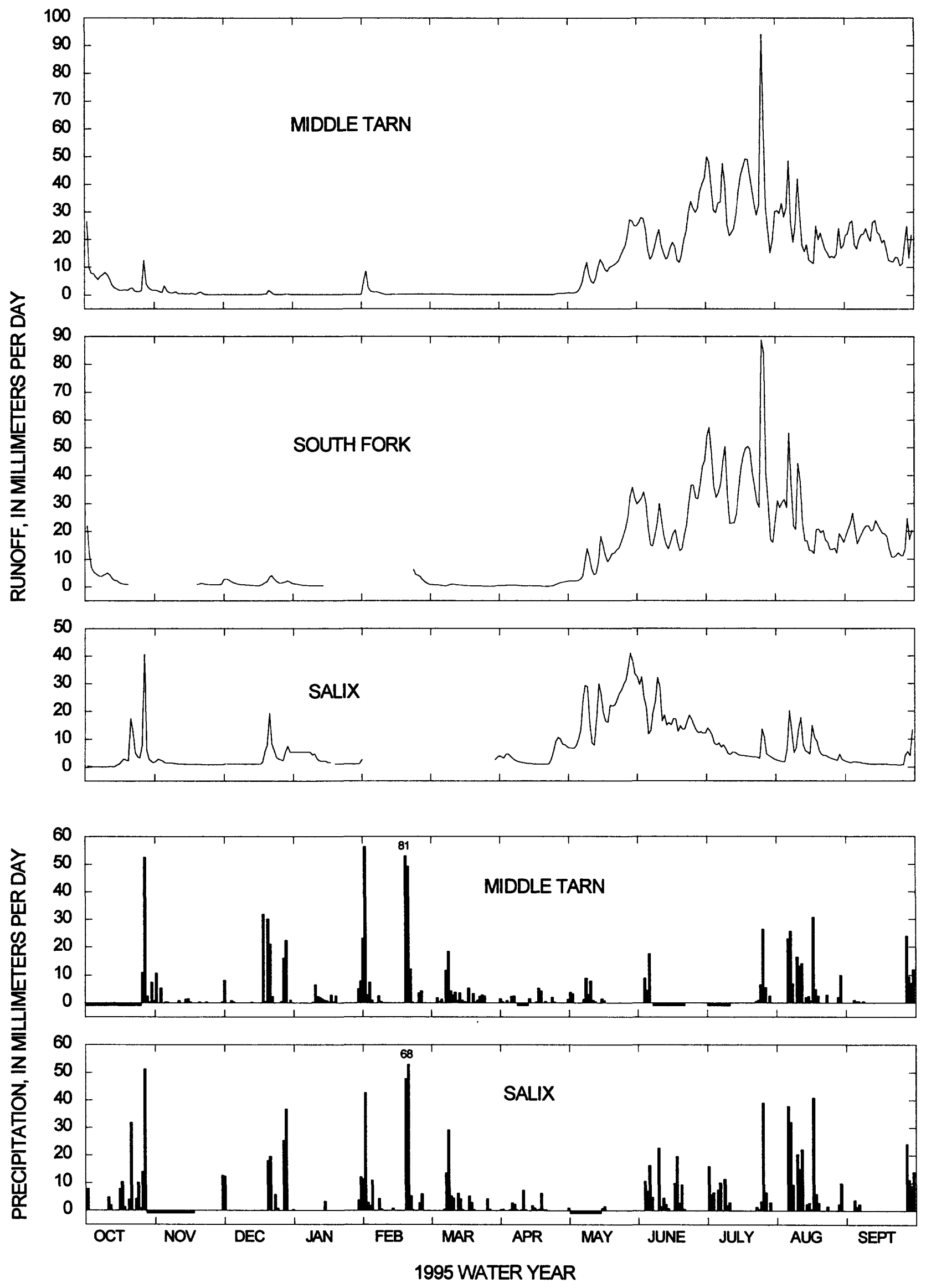

FIGURE 10. Runoff and precipitation near South Cascade Glacier during the 1995 water year. A negative precipitation indicates there were no data on that day. 


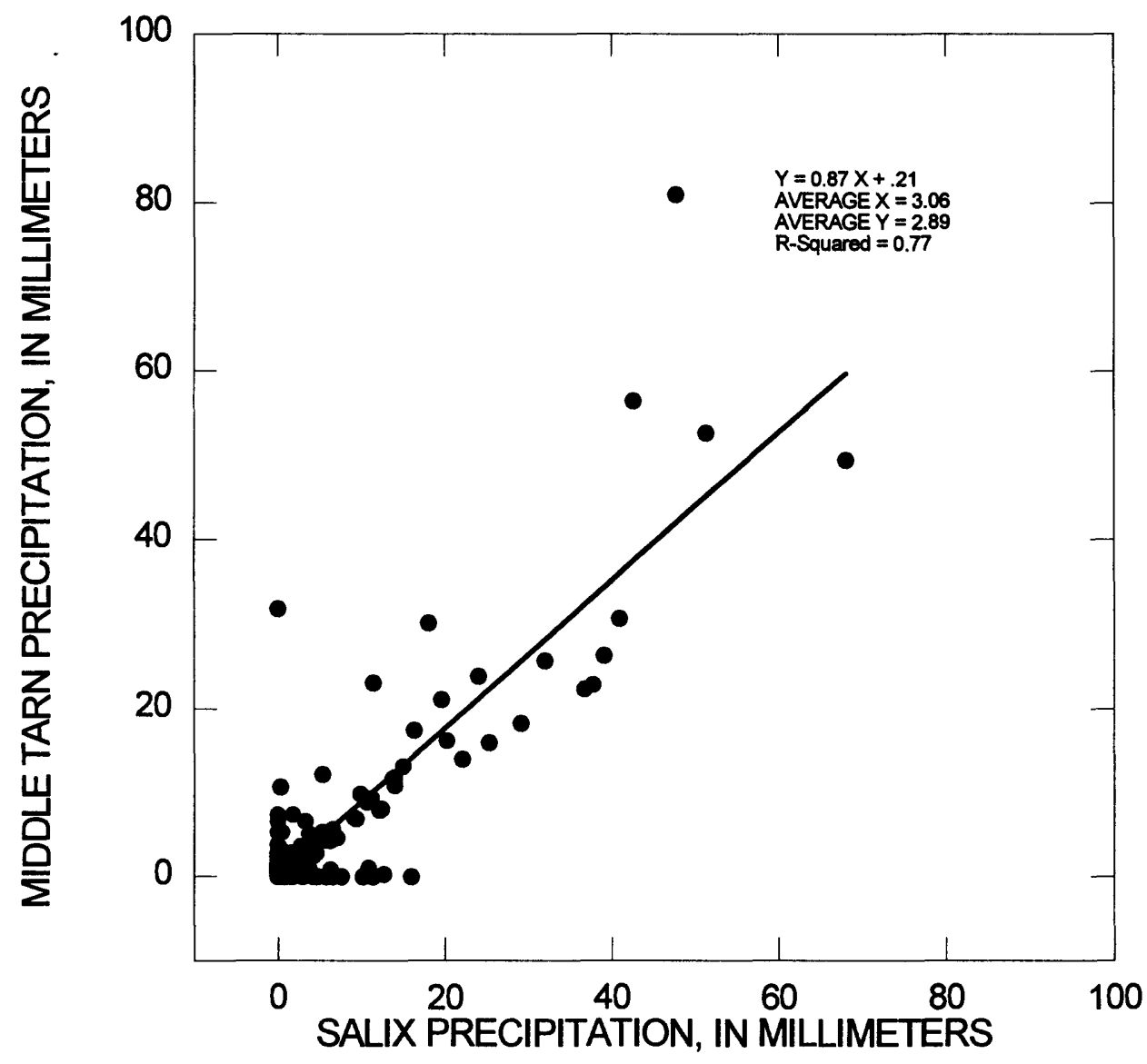

FIGURE 11. Middle Tarn and Salix precipitation for 1995 water year.
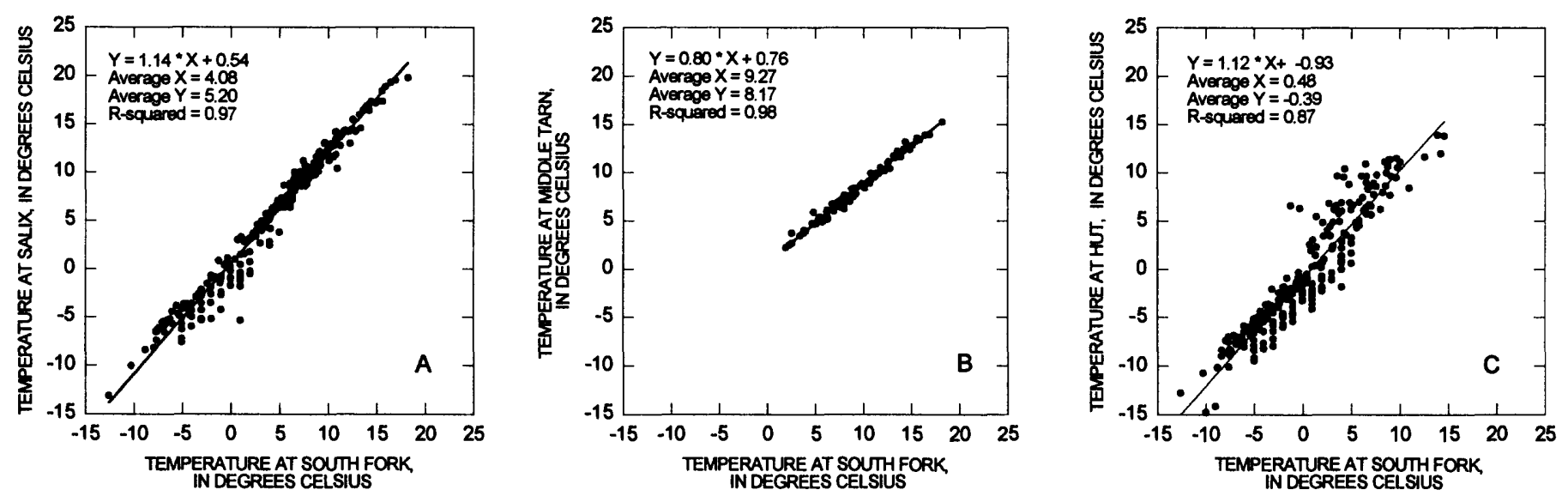

FIGURE 12. Correlation of air temperature at the South Fork gaging station with air temperature at Salix (A), Middle Tarn (B), and the Hut (C). 

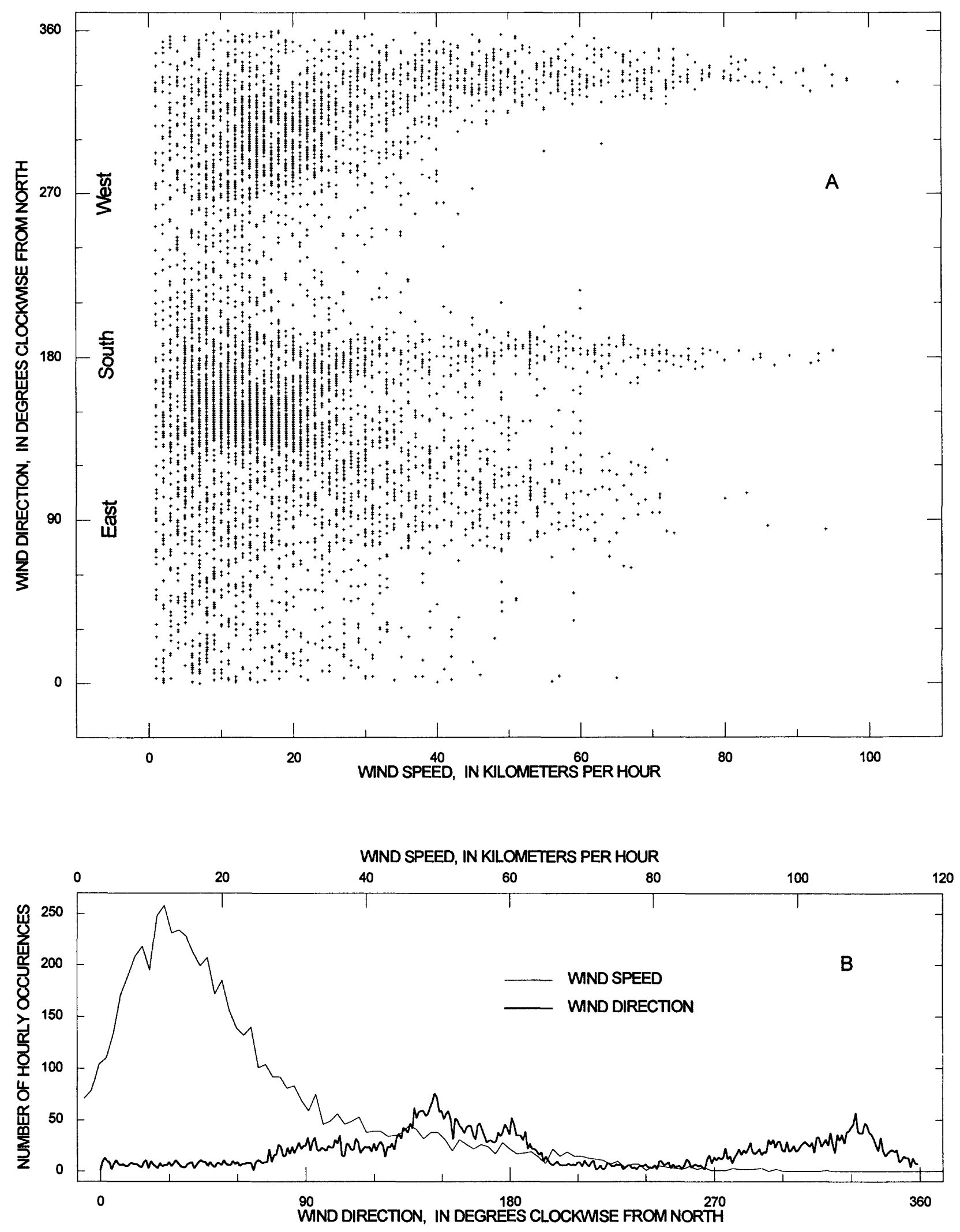

FIGURE 13. Wind direction and wind speed at Middle Tarn during the 1995 water year, plotted against each other (A), Frequency of occurrence of wind speed and direction (B). 


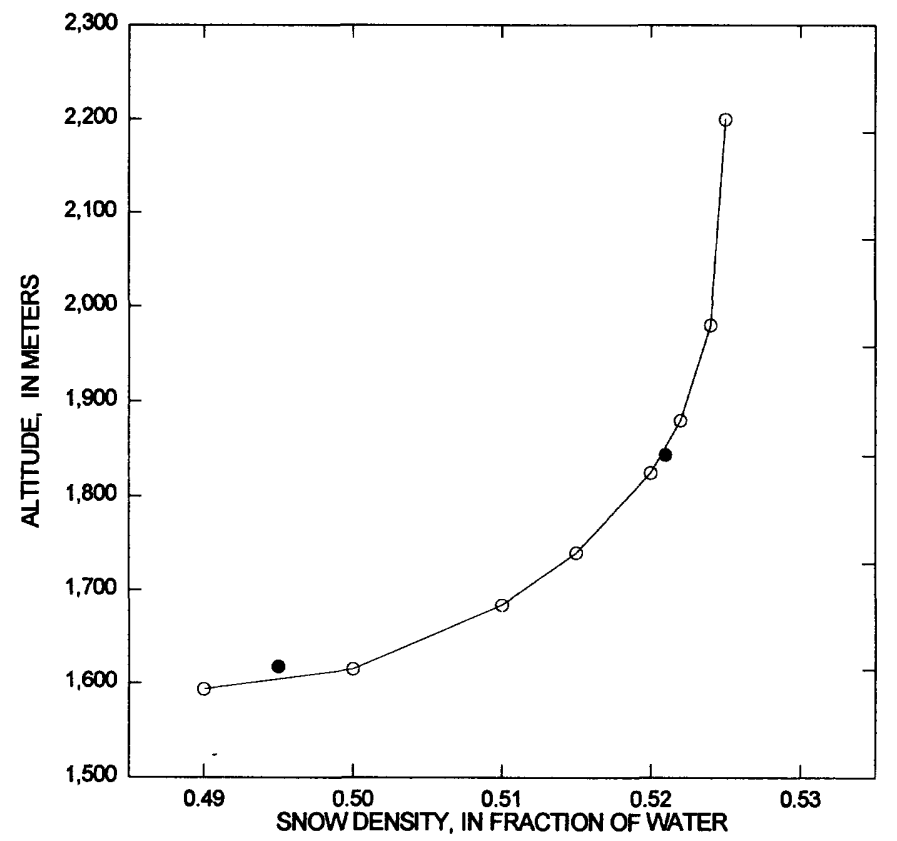

FIGURE 14. Snow density as a function of altitude at South Cascade Glacier, May 15-16, 1995. Solid circles are measured, open circles are points along a hand-drawn curve used for interpolation.

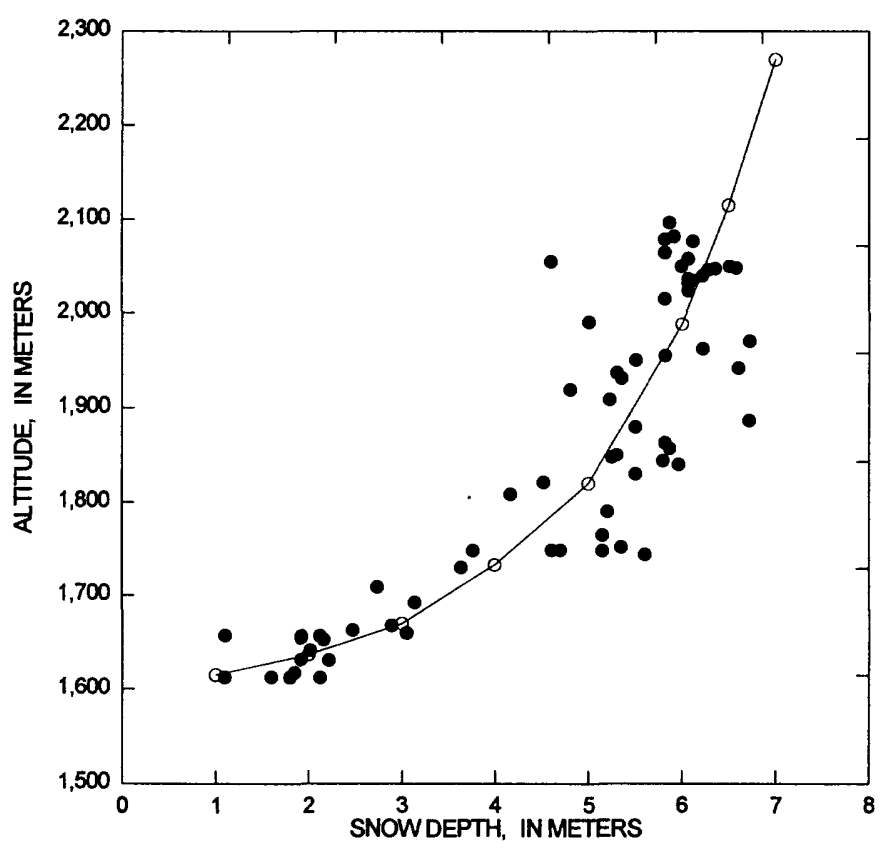

FIGURE 15. Snow depth as a function of altitude at South Cascade Glacier, May 15-16, 1995. Solid circles are measured, open circles are points along a hand-drawn curve used for interpolation.

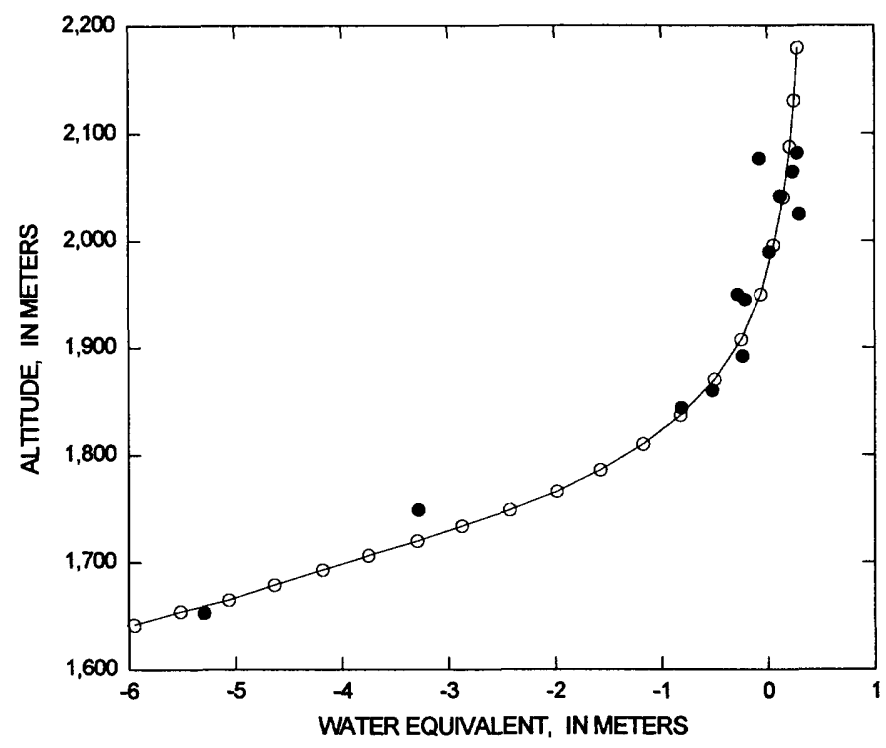

FIGURE 16. Net balance as a function of altitude at South Cascade Glacier, 1995. Solid circles are measured, open circles are along a hand-drawn curve used for interpolation. 


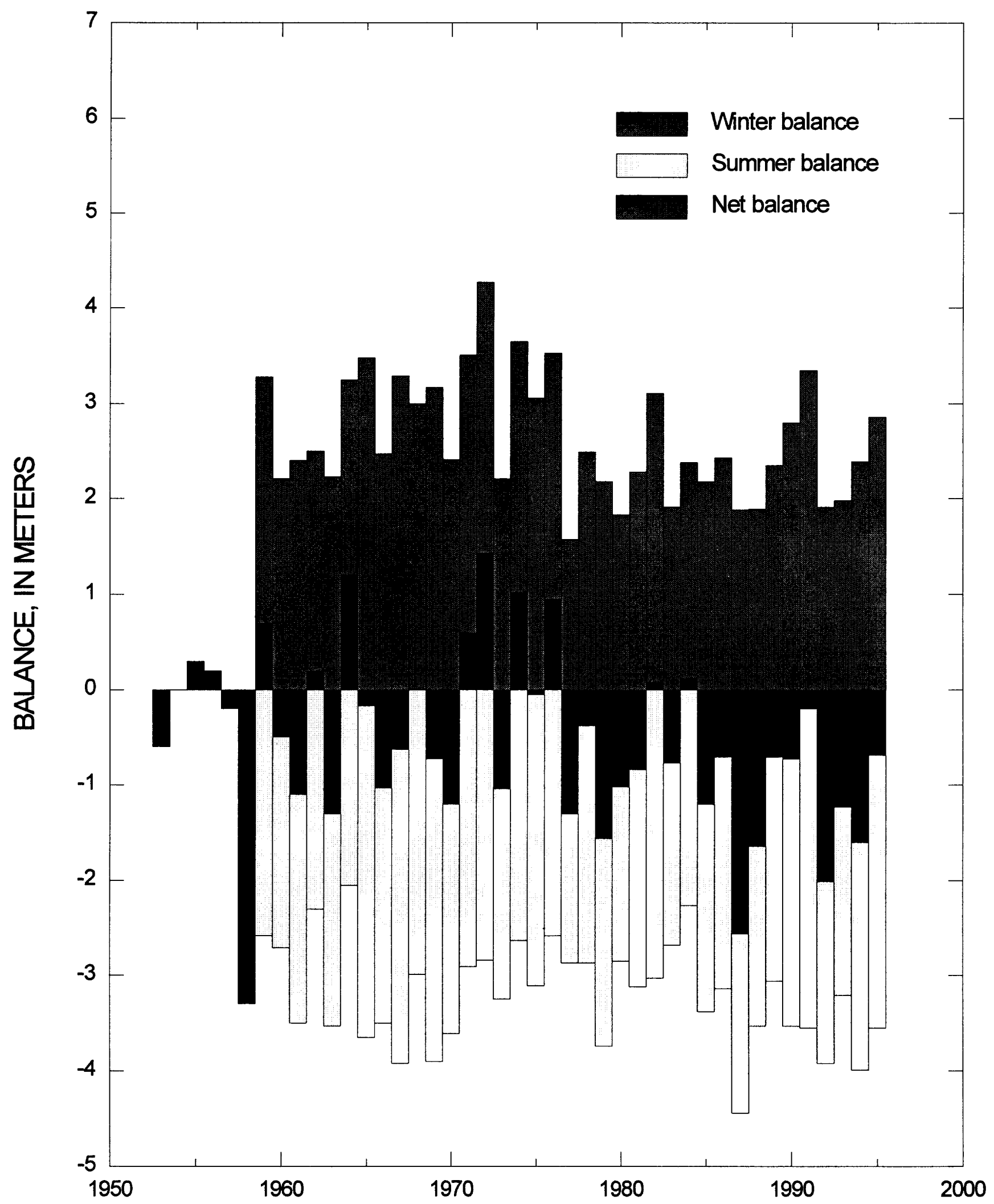

FIGURE 17. Winter, summer, and net mass balances for South Cascade Glacier, 1953-95. Data from Meier and Tangborn (1965) and Krimmel (1995). 


\begin{tabular}{|c|c|c|c|c|c|c|c|}
\hline & 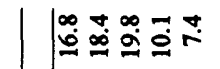 & 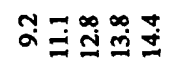 & 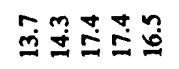 & 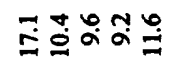 & 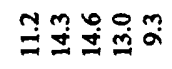 & 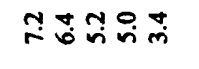 & İ \\
\hline & 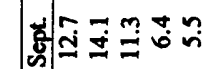 & 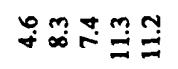 & 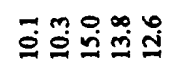 & 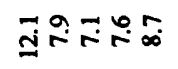 & 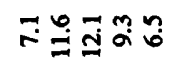 & 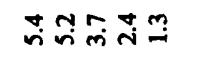 & \\
\hline$\dot{\alpha}$ & |a & 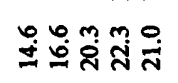 & 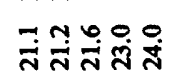 & 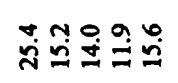 & mَّ & 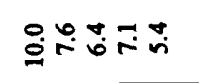 & \\
\hline$\dot{\Xi}$ & ب0 & 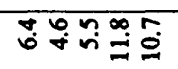 & ढ̆ & ثึ & 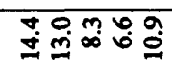 & 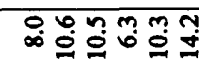 & \& \\
\hline$\underbrace{00}_{\mathscr{C}}$ & 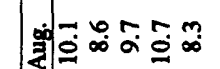 & 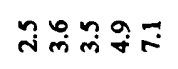 & nี่ & 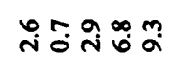 & 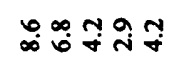 & 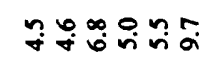 & \\
\hline 흘 & هُ & 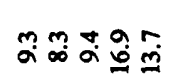 & 조ำ & 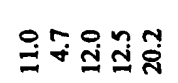 & 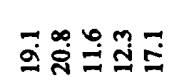 & 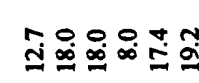 & \\
\hline $\begin{array}{l}5 \\
5 \\
00 \\
=\end{array}$ & 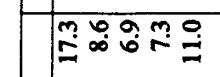 & 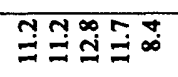 & 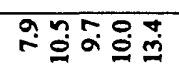 & 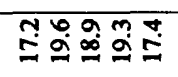 & 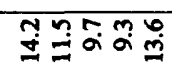 & 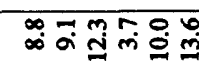 & $\stackrel{\infty}{=}$ \\
\hline 焉 & 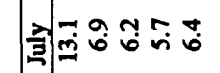 & 유ㅇㅠㅜㅁำ & 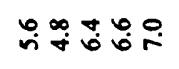 & 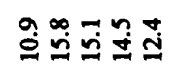 & 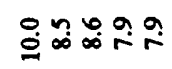 & 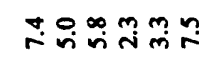 & \\
\hline 鸟 & 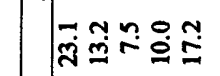 & 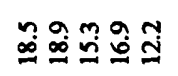 & 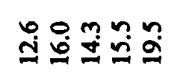 & 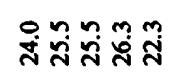 & Q & 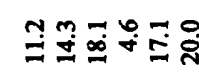 & \\
\hline$\underset{x}{*}$ & 웅 & 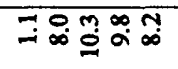 & 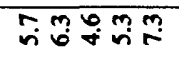 & 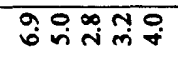 & 官只事可 & 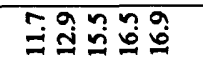 & $\infty$ \\
\hline ळึ & 递要 & 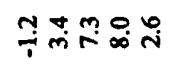 & 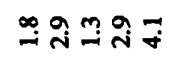 & ูํำ & 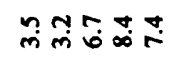 & $\vec{\forall} \stackrel{\infty}{\sim} \stackrel{n}{=} \stackrel{m}{=} \stackrel{m}{m}$ & \\
\hline$\vec{\pi}$ & 递安 & 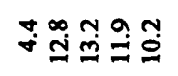 & בุ & 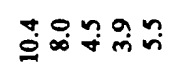 & 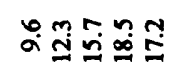 & 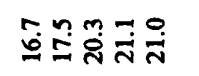 & \\
\hline$\exists$ & \%: & \&:8\%: & \&ั: & \&ूं mं & ํㅜㅇํํ용 & 舫 & 1 \\
\hline & $=28: 80.80$ & 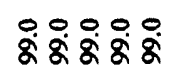 & \&영영영 & 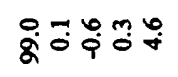 & 붕 뭉움 & 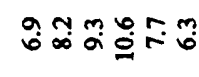 & \\
\hline & $\mid$ & \&̊영영 & \&영ㅇㅇㅇ & 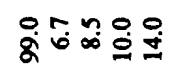 & 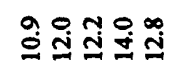 & 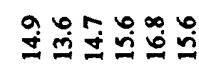 & \\
\hline E & \&:8영 & 웅ㅇㅇㅇ & 8.영ㅇㅇ & 8웅ㅇㅇㅇㅇ & 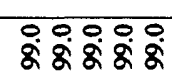 & 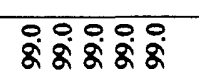 & 1 \\
\hline & 这 & 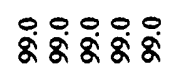 & \&영ㅇㅇㅇㅇㅇ & \&영ㅇㅇㅇㅇㅇ & \&영ㅇㅇㅇㅇ & รั:영요 & \\
\hline 苞 & $\mid \begin{array}{l}80 \\
8 \\
8\end{array}$ & 영영ㅇㅇㅇ & \&영영영 & \&영영영 & 영영영ㅇํ & 영영영영 & \\
\hline 总 & 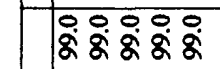 & \&ั: & \&ㅇㅇㅇㅇㅇㅇㅇㅇ & รั웅ㅇㅇㅇㅇㅇ & \&்:영ㅇㅇ & \%8: & 1 \\
\hline$E$ & $\mid$ & 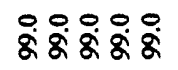 & 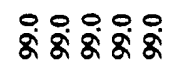 & 8영영영 & 8영영 & 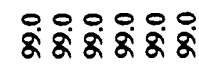 & \\
\hline$\approx$ & \&영영영 & \&영ㅇㅇㅇㅇㅇ & \&்:영ㅇㅇㅇ & \&்:영ㅇㅇㅇㅇ & 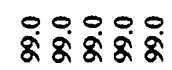 & \&영영ㅇㅇㅇ & \\
\hline 瓷 & 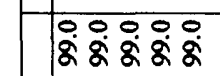 & 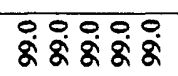 & ৪영ㅇㅇㅇㅇ & 8영ㅇㅇㅇㅇㅇ & 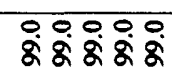 & $8: 800$ & 1 \\
\hline$z$ & 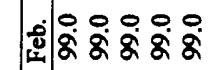 & 8영ㅇㅇㅇㅇㅇ & 8영ㅇㅇㅇ영 & \&영영영 & 8영영 & 웅영 & \\
\hline సี & $\mid \frac{0}{8} 8 \circ 800$ & 8영ㅇㅇㅇ & 8영영영 & 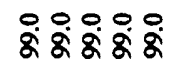 & 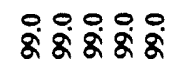 & $80 \div 8$ & \\
\hline. & 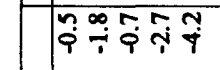 & 7영영영 & 8영ㅇㅇㅇ & \&영ㅇㅇㅇㅇㅇ & 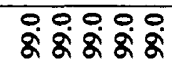 & 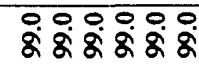 & 1 \\
\hline$\frac{E}{\pi}$ & 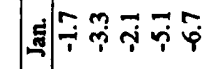 & テั & 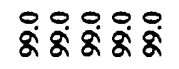 & 8영ㅇㅇ & ஷั8: & 8: $8:$ & \\
\hline 。 & 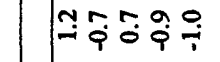 & ตั & 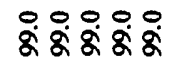 & \$영여 & ร영ㅇㅇ & 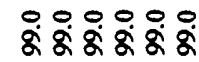 & \\
\hline 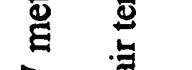 & 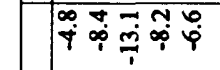 & 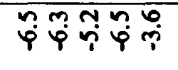 & 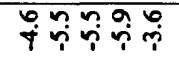 & 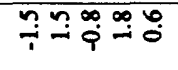 & 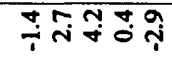 & 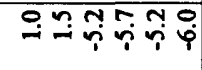 & $\frac{n}{9}$ \\
\hline 噉 & 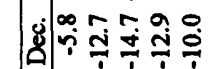 & 䒘 & 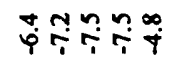 & 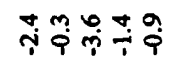 & 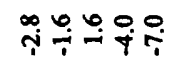 & 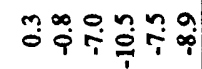 & \\
\hline$\pi$ & †े & 它守审 & 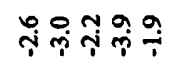 & 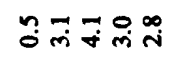 & 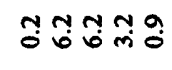 & تَ & \\
\hline$\stackrel{\circlearrowright}{\Xi}$ & 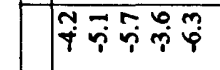 & พั่ & †ับั & 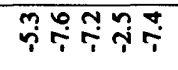 & 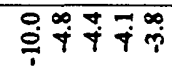 & 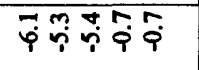 & F \\
\hline 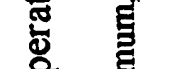 & (B⿱宀⿻三丨口 & 角战审审 & †ீ & 范审审䒘审 & 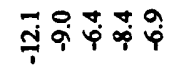 & 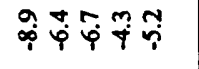 & \\
\hline & จิ์ & تَّْ & 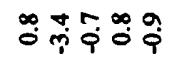 & 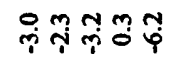 & 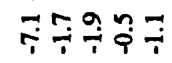 & 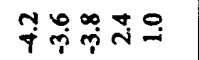 & \\
\hline & 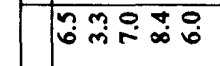 & 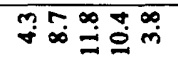 & 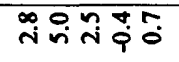 & 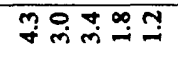 & कீ & 冓구ำ & \\
\hline 옳 & 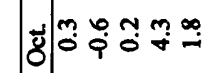 & 我宅 & 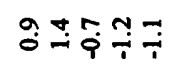 & 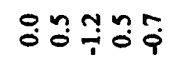 & † & 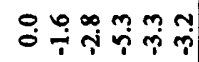 & \\
\hline 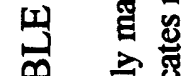 & $\begin{array}{l}n \\
\dot{m} \\
\dot{m}\end{array}$ & 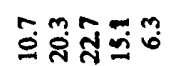 & mị & 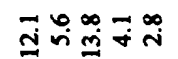 & 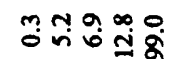 & & \\
\hline 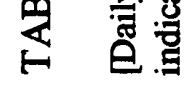 & $\left|\begin{array}{l}\mid \vec{a} \\
\mid\end{array}\right|-N m+n$ & bro & $\Xi \simeq \cong \pm \cong$ & $\begin{array}{l}25 \\
25\end{array}$ & $\widetilde{N} \approx \tilde{N}$ & & \\
\hline
\end{tabular}




\begin{tabular}{|c|c|c|c|c|c|c|c|}
\hline & 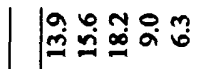 & 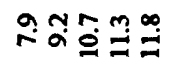 & 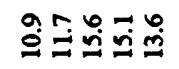 & 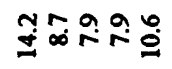 & 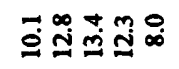 & மூن & om \\
\hline & 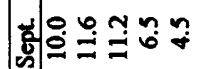 & 的? & 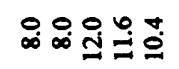 & 옹ㅎํ & 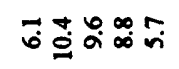 & 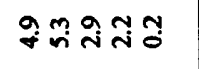 & \\
\hline 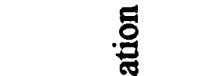 & 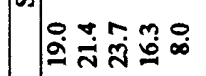 & 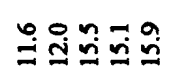 & 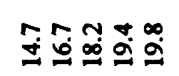 & 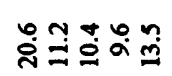 & 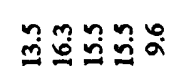 & 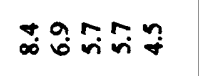 & \\
\hline $\begin{array}{l}5 \\
5 \\
00 \\
E\end{array}$ & 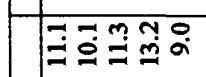 & $\tilde{n}$ & 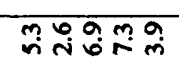 & 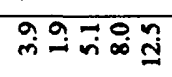 & 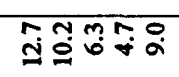 & 붕요 & ְיi \\
\hline 焉 & 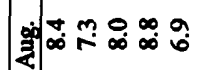 & 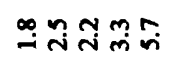 & 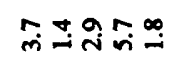 & సุํฺุ & ดิำกำ & 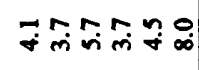 & \\
\hline ל. & 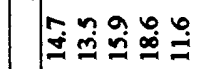 & 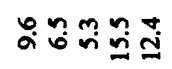 & 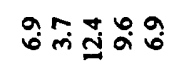 & 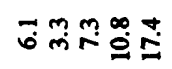 & 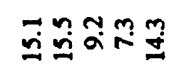 & 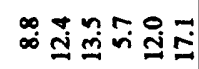 & \\
\hline 票 & $\underset{j}{0} \stackrel{0}{0}$ & 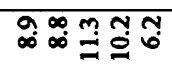 & 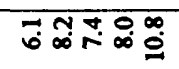 & 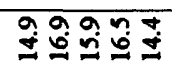 & $\stackrel{\infty}{0} \sigma:+\infty$ & 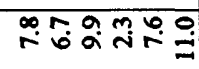 & $a$ \\
\hline J్ & 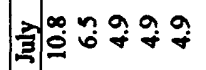 & 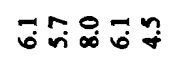 & 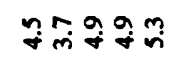 & 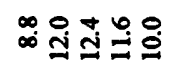 & 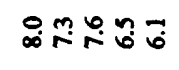 & $\tilde{6}$ & \\
\hline 항 & 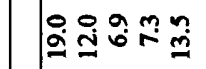 & $\begin{array}{l}a \\
m \dot{m} \\
\dot{m}\end{array}$ & 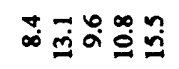 & ญี่ & 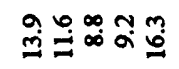 & 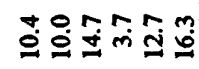 & \\
\hline 夆 & ?ำำ & Ṃ̂ñ & 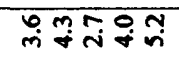 & 耐 & $\stackrel{\infty}{+\infty} \infty \hat{\infty} \tilde{\sigma} \vec{a}$ & 9 ô & 7 \\
\hline ஜ & ติ & 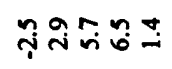 & 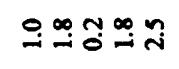 & فذ: & 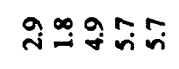 & 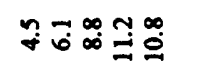 & \\
\hline 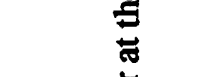 & 둥웡 & సَં & กี & 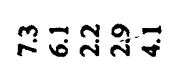 & 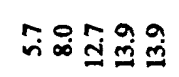 & 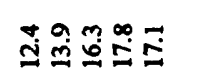 & \\
\hline & 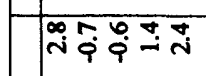 & 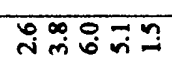 & ㄱํำ & 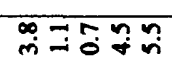 & 웅뭉 & 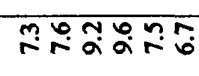 & $?$ \\
\hline ? & 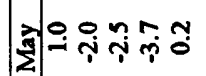 & 꿍융 車웅 & จิษ & 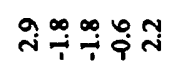 & 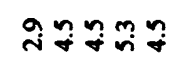 & 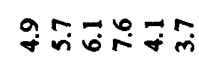 & \\
\hline 莺 & 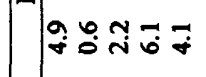 & กั่ & 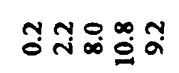 & 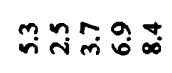 & $\begin{array}{l}\infty \\
\infty \\
\infty\end{array}$ & تُ & \\
\hline 兽 & సิ่ & 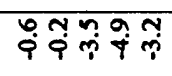 & 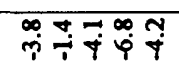 & 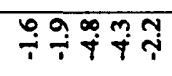 & 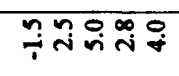 & 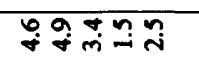 & : \\
\hline 范 & ติ่ & 華 & 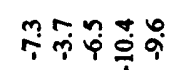 & ซิ宀 & 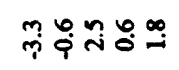 & 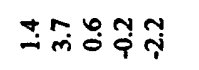 & \\
\hline 量 & 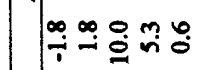 & 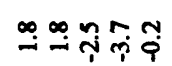 & 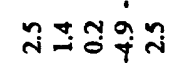 & సั & 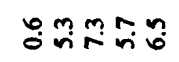 & 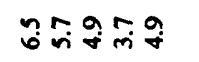 & \\
\hline$<$ & 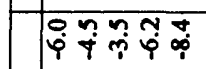 & 彳ัnọ & 商 & 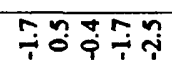 & 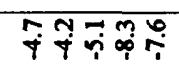 & 궁요 : & 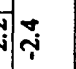 \\
\hline$E$ & $\mid$ & 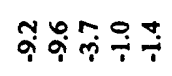 & 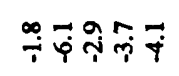 & $F \stackrel{+}{T} \underset{T}{*} \dot{q}$ & 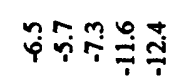 & 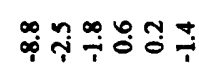 & \\
\hline$\overline{0}$ & | & 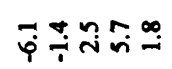 & 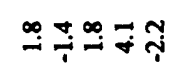 & 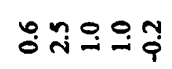 & $\ddot{p} \underset{p}{\dot{p}} \vec{p} \vec{\varphi} \dot{\varphi}$ & 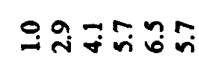 & \\
\hline 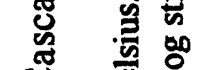 & 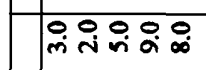 & 웅요웅요 & 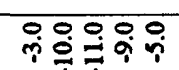 & 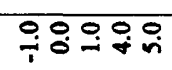 & 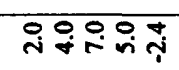 & $\stackrel{\varphi}{\varphi} \stackrel{n}{+}$ & 0 \\
\hline 5 & 영 & ৪영영영 & 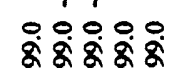 & 这这这这这 & 영영우 & فํำ & \\
\hline ठृ & $\mid$ & \&영영영 & 웅영영영 & \&:8영영 & \&:영영 & $\stackrel{\infty}{i} \underset{i}{\sim} \underset{i}{n}$ & \\
\hline$\stackrel{8}{0}$ & 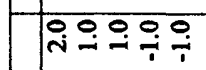 & 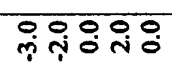 & 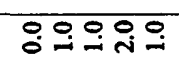 & 욱웅욱 & 입윰우요 & 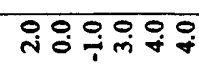 & 10 \\
\hline \pm & fl & 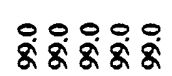 & 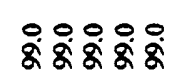 & \&:영영 & \$영ㅇㅇ & 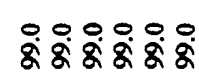 & \\
\hline q & 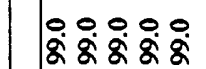 & 8:8\%8: & \&: & \&:8\% & \&:80ㅇㅇㅇㅇ & $8: 0$ & \\
\hline छ & 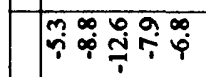 & 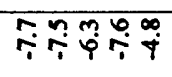 & ڤ̆ & 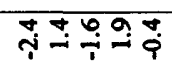 & 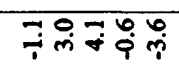 & 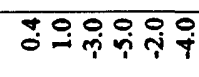 & $\infty$ \\
\hline 5 & ن் & 审苑 & 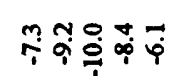 & 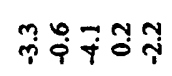 & 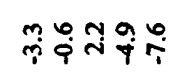 & 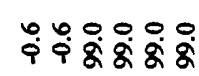 & \\
\hline$\Rightarrow$ & $\exists$ †ำ & 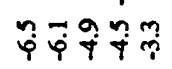 & 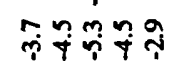 & 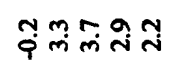 & ิㅡㅇำ & 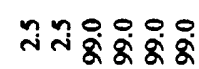 & \\
\hline 岇 & 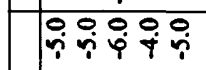 & 욱웅우 & 宁守 & 움ํํำ & @ํํํ & mִn & 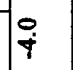 \\
\hline 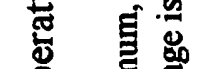 & | & 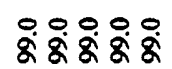 & รั8영ㅇ & 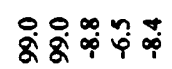 & 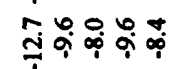 & 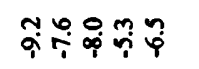 & \\
\hline$\exists$ & 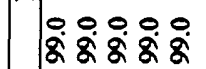 & 官:영영 & 영영영 & 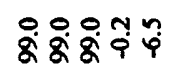 & 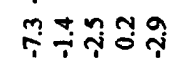 & 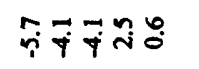 & \\
\hline 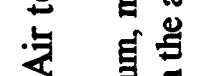 & ที่ง & 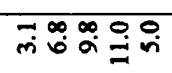 & 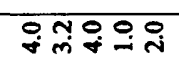 & ஸ் & 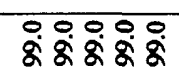 & ஷ்유 & : \\
\hline $\bar{x}$ & 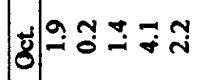 & 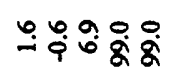 & \&ั0 & ๆ & 웅영영 & 영용ㅇㅇ & \\
\hline 딜 & 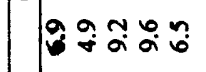 & 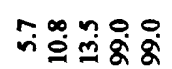 & 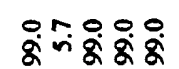 & 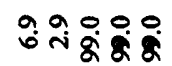 & \&영ㅇㅇㅇㅇㅇ & 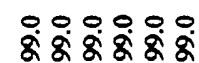 & \\
\hline فํ & $|\vec{x}|-n m+n$ & or $\infty$ a & $\exists \simeq \cong \pm \cong$ & 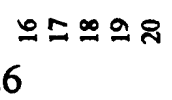 & สสヌニぇ & & \\
\hline
\end{tabular}




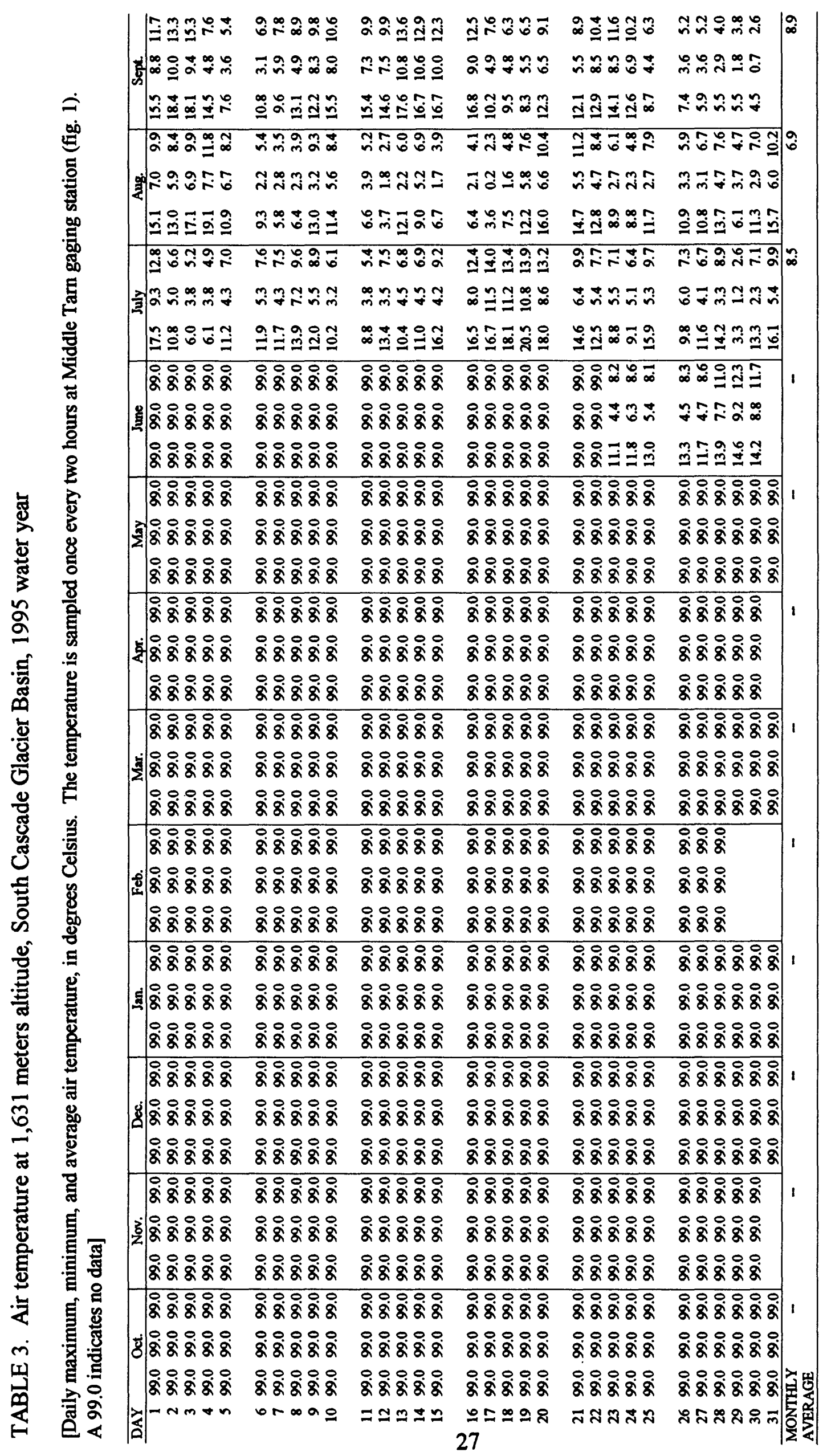




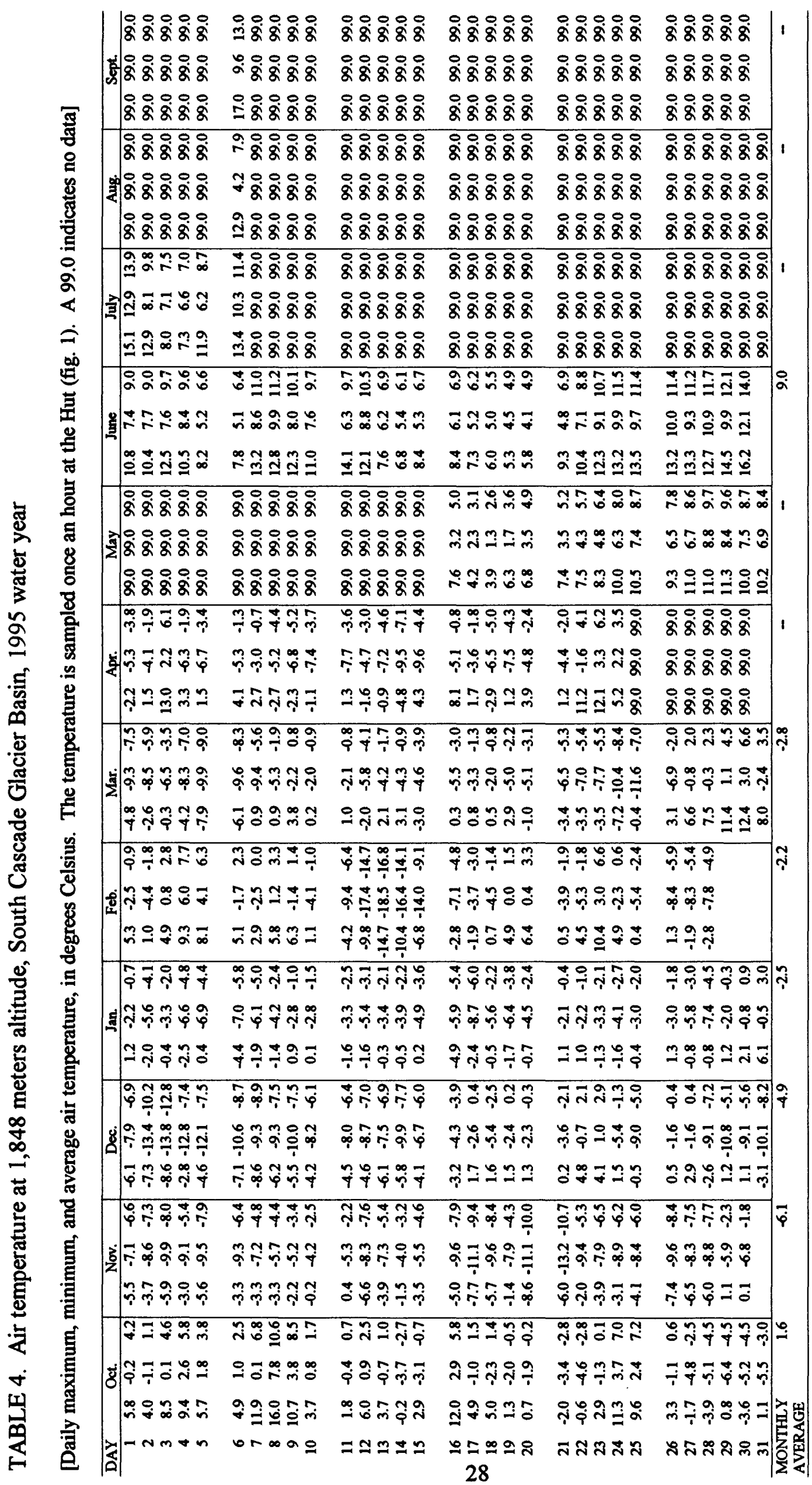




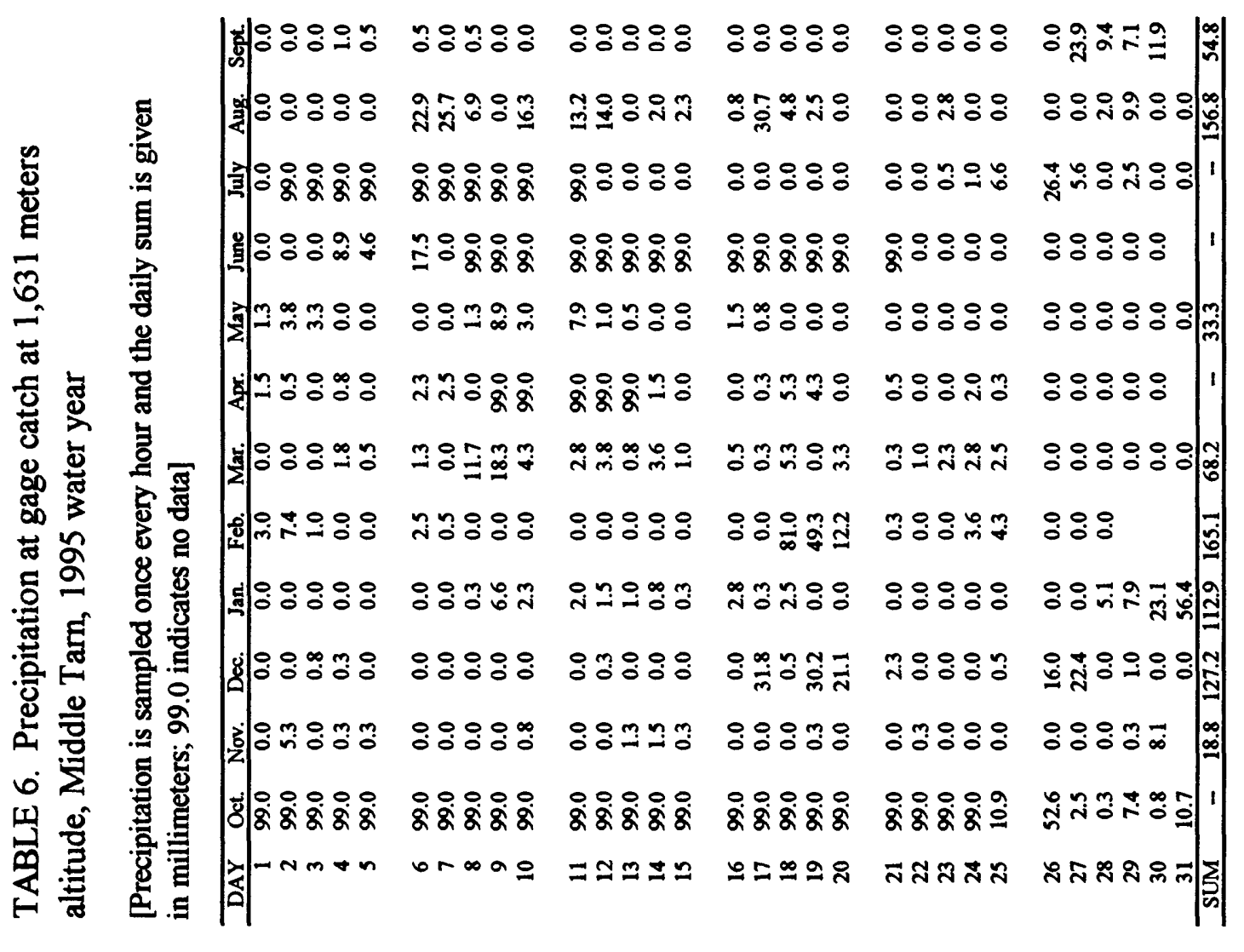

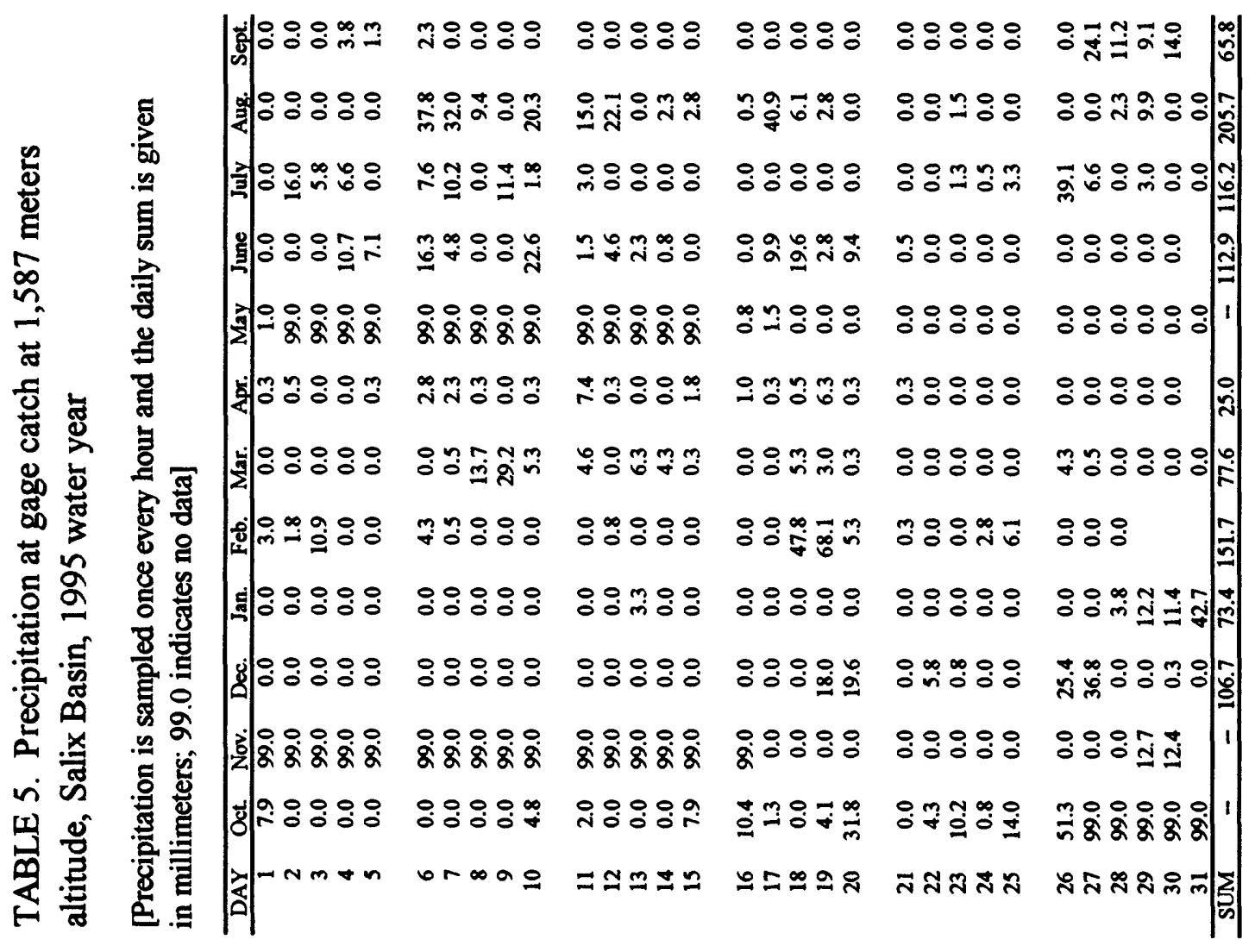




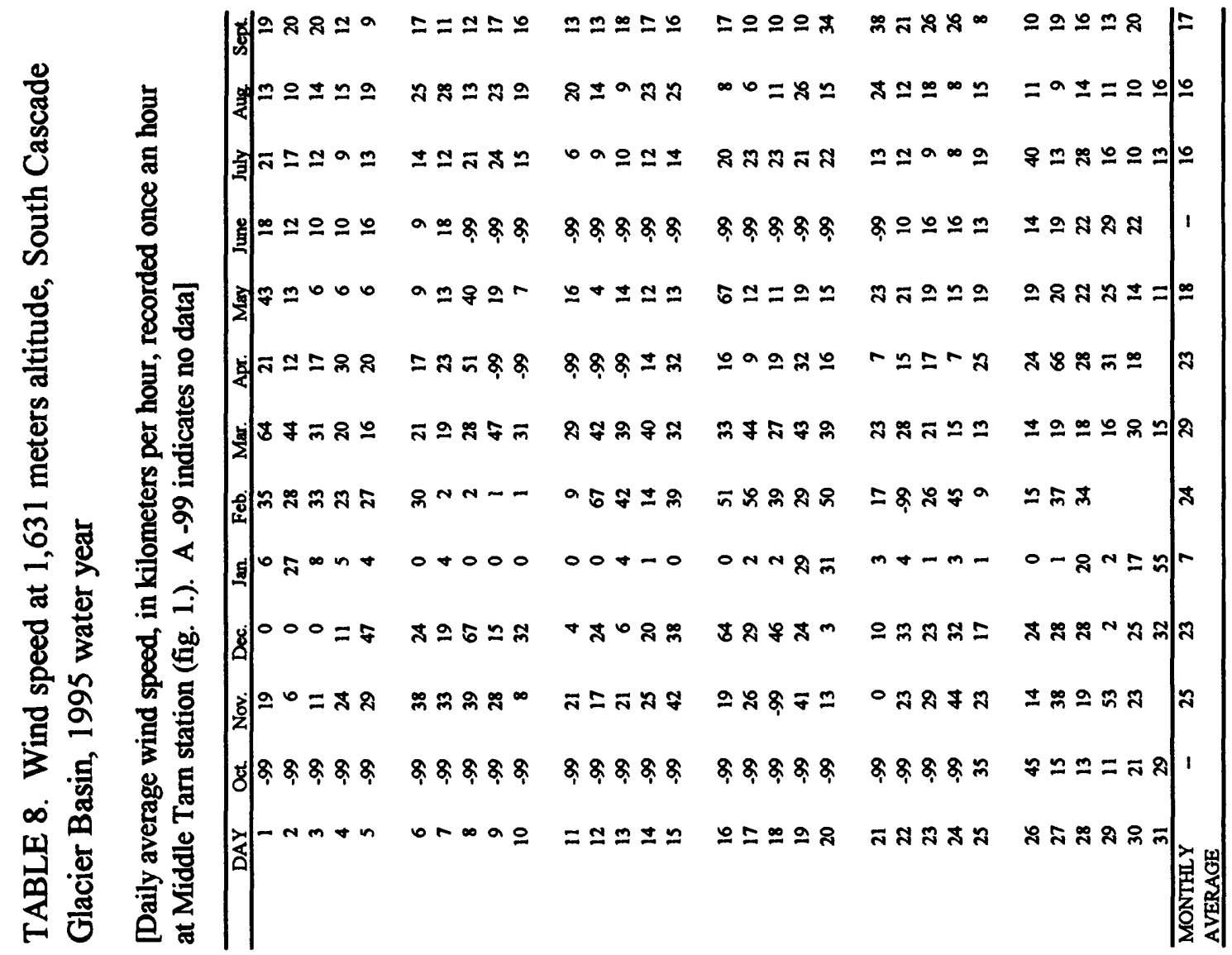

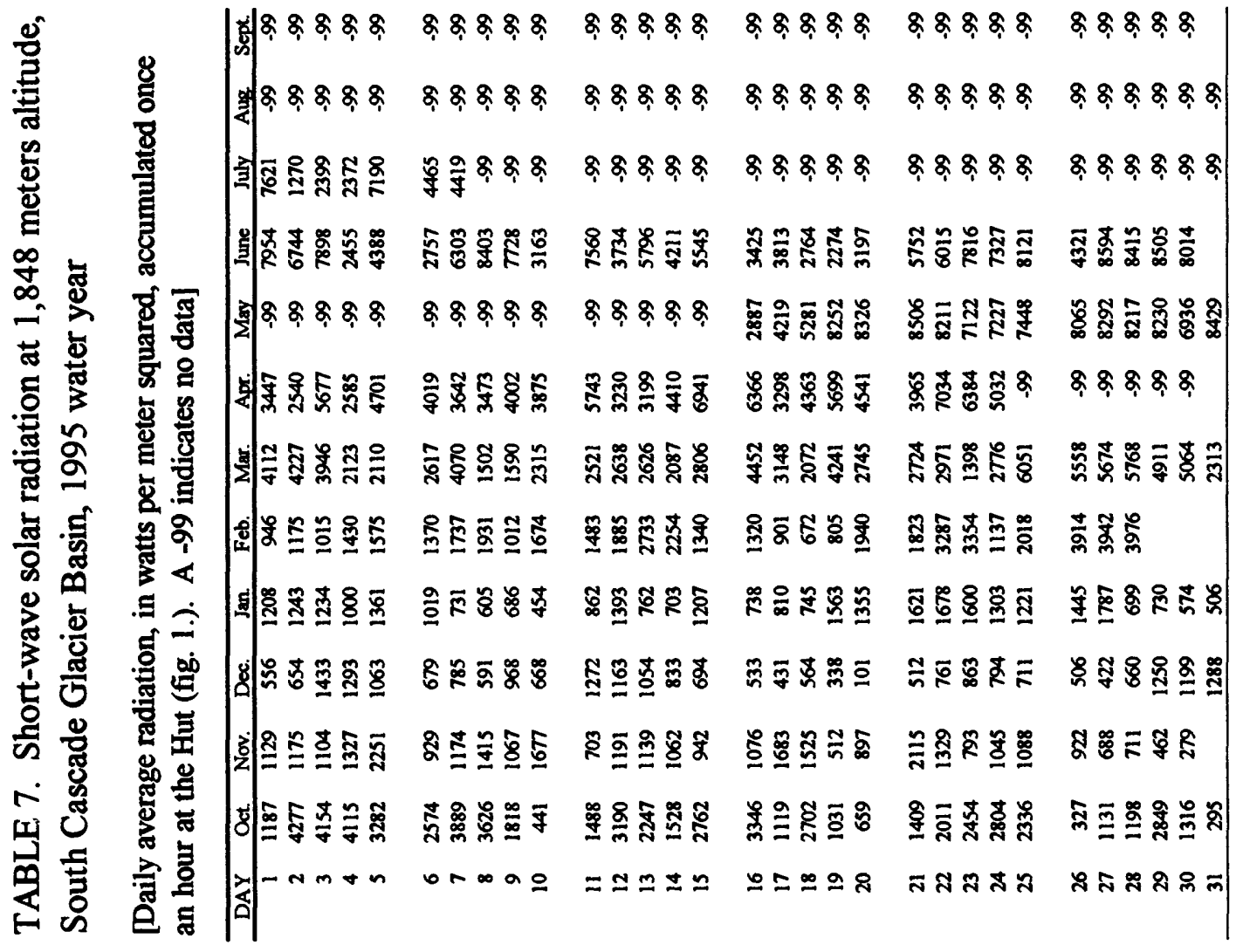


TABLE 9. Snow depths at South Cascade Glacier, May 15-16, 1995

[Depths; in meters (m) measured with a probe rod: $\mathrm{X}, \mathrm{Y}$, and $\mathrm{Z}$ are local coordinates, \pm 100 meters]

\begin{tabular}{cccccccc|cccccccc}
\hline $\mathrm{X}$ & $\mathrm{Y}$ & $\mathrm{Z}$ & $\begin{array}{c}\text { Snow } \\
\text { depth } \\
(\mathrm{m})\end{array}$ & $\mathrm{X}$ & $\mathrm{Y}$ & $\mathrm{Z}$ & $\begin{array}{c}\text { Snow } \\
\text { depth } \\
(\mathrm{m})\end{array}$ & $\mathrm{X}$ & $\mathrm{Y}$ & $\mathrm{Z}$ & $\begin{array}{c}\text { Snow } \\
\text { depth } \\
(\mathrm{m})\end{array}$ & $\mathrm{X}$ & $\mathrm{Y}$ & $\mathrm{Z}$ & $\begin{array}{c}\text { Snow } \\
\text { depth } \\
(\mathrm{m})\end{array}$ \\
\hline & & & & & & & & & & & & & & & \\
2523 & 1403 & 2058 & 6.07 & 1888 & 2782 & 1848 & 5.25 & 2364 & 1823 & 2015 & 5.82 & 1819 & 3536 & 1663 & 2.47 \\
2531 & 1433 & 2055 & 4.60 & 1852 & 2849 & 1844 & 5.80 & 2320 & 1865 & 1990 & 5.00 & 1717 & 3637 & 1658 & 1.10 \\
2542 & 1470 & 2050 & 6.51 & 1795 & 2912 & 1840 & 5.97 & 2263 & 1902 & 1970 & 6.72 & 1749 & 3622 & 1657 & 2.12 \\
2546 & 1512 & 2049 & 6.58 & 1740 & 2969 & 1830 & 5.50 & 2225 & 1952 & 1962 & 6.22 & 1780 & 3614 & 1657 & 1.92 \\
2557 & 1544 & 2048 & 6.36 & 1690 & 3030 & 1821 & 4.52 & 2189 & 2010 & 1955 & 5.82 & 1814 & 3596 & 1653 & 2.16 \\
2567 & 1581 & 2046 & 6.28 & 1650 & 3093 & 1809 & 4.17 & 2161 & 2075 & 1950 & 5.50 & 1842 & 3558 & 1655 & 1.92 \\
2574 & 1616 & 2040 & 6.22 & 1633 & 3159 & 1790 & 5.20 & 2130 & 2140 & 1942 & 6.60 & 1871 & 3517 & 1660 & 3.05 \\
2584 & 1653 & 2037 & 6.07 & 1644 & 3224 & 1765 & 5.15 & 2101 & 2212 & 1937 & 5.30 & 1902 & 3487 & 1668 & 2.89 \\
2669 & 1669 & 2050 & 6.00 & 1498 & 3289 & 1752 & 5.35 & 2075 & 2278 & 1931 & 5.35 & 1804 & 3645 & 1642 & 2.02 \\
2765 & 1683 & 2065 & 5.82 & 1547 & 3292 & 1749 & 4.70 & 2050 & 2340 & 1919 & 4.80 & 1790 & 3698 & 1632 & 1.92 \\
2859 & 1701 & 2077 & 6.12 & 1594 & 3290 & 1748 & 5.15 & 2025 & 2401 & 1909 & 5.22 & 1774 & 3750 & 1631 & 2.22 \\
2959 & 1727 & 2079 & 5.82 & 1633 & 3292 & 1748 & 3.77 & 2001 & 2467 & 1887 & 6.72 & 1601 & 3966 & 1613 & 1.80 \\
3043 & 1747 & 2082 & 5.92 & 1682 & 3286 & 1749 & 4.61 & 1983 & 2524 & 1880 & 5.50 & 1548 & 3978 & 1613 & 2.12 \\
3143 & 1760 & 2097 & 5.87 & 1731 & 3281 & 1744 & 5.60 & 1965 & 2588 & 1863 & 5.82 & 1494 & 3992 & 1613 & 1.10 \\
2526 & 1695 & 2035 & 6.12 & 1720 & 3343 & 1730 & 3.64 & 1938 & 2654 & 1857 & 5.87 & 1451 & 4013 & 1613 & 1.60 \\
2467 & 1730 & 2032 & 6.07 & 1765 & 3405 & 1709 & 2.74 & 1911 & 2718 & 1850 & 5.30 & 0 & 0 & 1618 & 1.85 \\
2419 & 1772 & 2024 & 6.07 & 1801 & 3462 & 1692 & 3.14 & & & & & & & & \\
\hline
\end{tabular}

TABLE 10. Snow density near the South Fork Cascade gaging station, at 1,618 meters altitude, May 16, 1995

[Measured with a snow tube that penetrated the entire snowpack in one sample. The distance between sample locations was about $15 \mathrm{~m}$. WE = water equivalent]

\begin{tabular}{ccc}
\hline Sample & $\begin{array}{c}\text { Depth } \\
\text { (meters) }\end{array}$ & $\begin{array}{c}\text { WE } \\
\text { (meters) }\end{array}$ \\
\hline West end & 2.26 & 1.19 \\
2 & 2.34 & .90 \\
3 & 1.96 & .99 \\
4 & 1.78 & .84 \\
5 & 1.63 & .89 \\
6 & 1.55 & .81 \\
7 & 1.74 & .86 \\
East end & 1.56 & .84 \\
\hline Average depth $=1.85 \mathrm{~m}$ & \\
Average WE $=0.92 \mathrm{~m}$ & \\
Average density $=0.49$
\end{tabular}

TABLE 11. Snow density on South Cascade Glacier, at 1,844 meters altitude, May 15-16, 1995

[Measured in a snow pit, through the entire thickness of the snow, at local $X=1852, Y=2848, Z=1844$ meters]

\begin{tabular}{cccc}
\hline $\begin{array}{c}\text { Sample } \\
\text { bottom } \\
\text { depth } \\
\text { (meters) }\end{array}$ & $\begin{array}{c}\text { Sample } \\
\text { length } \\
\text { (meters) }\end{array}$ & $\begin{array}{c}\text { Mass } \\
\text { (grams) }\end{array}$ & Density \\
\hline 0.45 & 0.45 & 810 & 0.44 \\
0.88 & .43 & 830 & .47 \\
1.30 & .42 & 875 & .51 \\
1.71 & .41 & 835 & .50 \\
2.18 & .47 & 1015 & .53 \\
Begin using coring auger & & \\
3.00 & .82 & 1740 & .48 \\
3.75 & .75 & 1820 & .53 \\
4.53 & .78 & 2215 & .55 \\
5.27 & .74 & 1975 & .59 \\
5.54 & .27 & 560 & .58 \\
\hline
\end{tabular}

Total water equivalent $=2.88$ meters

Average density $=0.52$ 
TABLE 12. Stake measurements at South Cascade Glacier in the 1995 balance year

[Surface material may be snow (s), firn (f), or ice (i); density estimated based on interpolation between measurements made in early May, and assumed density of firn of 0.7 . Balance is the gain or loss of material, referenced to the previous year's melt horizon, in water content. Local X, Y, and Z coordinates (in meters) given for each stake. Stake locations shown on fig. 1]

\begin{tabular}{ccccc}
\hline Date & $\begin{array}{c}\text { Surface } \\
\text { material }\end{array}$ & $\begin{array}{c}\text { Depth } \\
\text { (meters) }\end{array}$ & Density & $\begin{array}{c}\text { Balance } \\
\text { (meters) }\end{array}$ \\
\hline
\end{tabular}

Stake 1-95 $[X=2584, Y=1653, Z=2037]$

\begin{tabular}{lllll}
\hline May 15 & s & 5.92 & 0.52 & 3.08 \\
July 11 & s & 3.30 & .55 & 1.82 \\
August 22 & s & 1.40 & .58 & 0.81 \\
September 12 & s & 0.57 & .59 & 0.34 \\
Minimum $^{1}$ & S & 0.22 & .60 & 0.13 \\
\hline
\end{tabular}

Stake 2-95 $[X=1852, Y=2849, Z=1844]$

\begin{tabular}{llccc}
\hline May 15 & s & 5.50 & 0.52 & 2.86 \\
June 7 & s & 4.73 & .53 & 2.51 \\
July 11 & s & 2.76 & .55 & 1.52 \\
Aug. 22 & s & 0.60 & .58 & 0.35 \\
Sept. 12 & i & -0.27 & .90 & -0.24 \\
Minumum & $\mathrm{i}$ & -0.90 & .90 & -0.81 \\
\hline
\end{tabular}

Stake 3-95 $[X=1682, Y=3286, Z=1749]$

\begin{tabular}{llccc}
\hline May 16 & S & 4.61 & 0.50 & 2.31 \\
July 11 & s & 1.27 & .55 & 0.70 \\
Aug. 22 & i & -1.67 & .90 & -1.50 \\
Sept. 12 & i & -2.85 & .90 & -2.57 \\
Minimum & i & -3.65 & .90 & -3.29 \\
\hline
\end{tabular}

Stake 4-95 $[X=1814, Y=3596, Z=1653$

\begin{tabular}{llccc}
\hline May 16 & s & 2.16 & 0.50 & 1.08 \\
June 7 & s & 1.17 & .55 & 0.64 \\
June 22 & s & 0.54 & .57 & 0.31 \\
July 11 & i & -1.09 & .90 & -0.98 \\
Aug. 22 & i & -3.76 & .90 & -3.38 \\
Sept. 12 & i & -4.91 & .90 & -4.42 \\
Minimum & i & -5.88 & .90 & -5.29 \\
\hline
\end{tabular}

- Minimum level of material at each stake was determined by measuring the level of the summer surface on November 15, 1995, after the snow accumulation began. 
TABLE 13. South Cascade Glacier elevation grid, September 12, 1995

[Surface altitude (Z), in meters above National Geodetic Vertical Datum of 1929, was measured near the nominal point for each grid cell. Coordinates $\mathrm{X}$ and $\mathrm{Y}$ are local (see fig. 8). The tenths of meters are marginally significant]

\begin{tabular}{|c|c|c|c|c|c|c|c|c|c|c|c|}
\hline $\mathbf{X}$ & Y & Z & $X$ & Y & $\mathbf{Z}$ & $\mathbf{X}$ & $Y$ & $Z$ & $X$ & $Y$ & $Z$ \\
\hline 2271.0 & 3000.5 & 1833.4 & 1771.6 & 2499.0 & 1877.9 & 2270.9 & 1999.1 & 1956.7 & 2671.3 & 1501.0 & 2064.8 \\
\hline 2170.9 & 3000.8 & 1831.2 & 1870.7 & 2500.3 & 1877.8 & 2370.3 & 2000.3 & 1967.2 & 2571.9 & 1501.6 & 2050.2 \\
\hline 2070.8 & 2998.5 & 1835.9 & 1969.6 & 2500.0 & 1880.7 & 2470.6 & 2002.4 & 1981.7 & 2470.9 & 1499.6 & 2046.1 \\
\hline 1969.9 & 2999.4 & 1837.4 & 2070.1 & 2500.0 & 1885.7 & 2470.8 & 1899.6 & 2008.1 & 2369.9 & 1501.0 & 2036.5 \\
\hline 1870.3 & 2999.3 & 1838.6 & 2169.8 & 2498.9 & 1898.5 & 2369.8 & 1901.0 & 1992.1 & 2272.3 & 1498.3 & 2037.7 \\
\hline 1769.8 & 2999.8 & 1832.4 & 2271.6 & 2499.3 & 1914.2 & 2271.9 & 1900.0 & 1984.9 & 2168.6 & 1497.2 & 2042.7 \\
\hline 1669.6 & 2998.8 & 1829.0 & 2369.6 & 2499.6 & 1926.1 & 2170.1 & 1901.8 & 1972.1 & 2270.9 & 1399.9 & 2074.8 \\
\hline 1570.7 & 2999.4 & 1829.1 & 2470.6 & 2400.0 & 1961.4 & 2068.3 & 1901.4 & 1970.6 & 2371.7 & 1400.6 & 2060.3 \\
\hline 1471.6 & 2998.2 & 1835.1 & 2371.5 & 2401.2 & 1941.9 & 1969.5 & 1897.9 & 1974.5 & 2471.7 & 1400.9 & 2055.2 \\
\hline 1472.0 & 2899.7 & 1848.9 & 2269.1 & 2401.5 & 1931.8 & 1868.1 & 1900.8 & 1989.4 & 2569.1 & 1400.0 & 2059.4 \\
\hline 1569.2 & 2901.6 & 1844.2 & 2169.9 & 2401.2 & 1917.1 & 1869.4 & 1800.1 & 2007.4 & 2670.4 & 1400.6 & 2089.2 \\
\hline 1671.5 & 2901.7 & 1843.0 & 2070.5 & 2401.3 & 1910.7 & 1970.1 & 1801.7 & 1995.3 & 2771.1 & 1401.1 & 2109.9 \\
\hline 1769.0 & 2898.8 & 1842.0 & 1969.1 & 2399.6 & 1907.2 & 2070.0 & 1800.2 & 1983.8 & 2273.9 & 3100.6 & 1797.7 \\
\hline 1871.2 & 2902.0 & 1844.0 & 1870.7 & 2400.4 & 1895.5 & 2172.0 & 1800.7 & 1991.6 & 2171.1 & 3099.2 & 1815.7 \\
\hline 1970.0 & 2900.6 & 1843.6 & 1769.4 & 2401.1 & 1891.5 & 2270.6 & 1799.2 & 2006.1 & 2070.0 & 3098.3 & 1825.1 \\
\hline 2071.5 & 2899.7 & 1841.9 & 1669.8 & 2398.8 & 1889.3 & 2370.8 & 1802.6 & 2020.1 & 1970.5 & 3101.0 & 1825.5 \\
\hline 2168.7 & 2901.3 & 1839.4 & 1571.6 & 2401.1 & 1896.2 & 2470.4 & 1799.0 & 2028.4 & 1871.7 & 3100.2 & 1825.9 \\
\hline 2271.2 & 2900.6 & 1831.5 & 1571.9 & 2300.8 & 1927.4 & 2571.9 & 1799.4 & 2037.6 & 1771.7 & 3100.4 & 1816.2 \\
\hline 2369.7 & 2898.9 & 1842.4 & 1670.9 & 2301.9 & 1908.7 & 2671.1 & 1801.9 & 2054.8 & 1670.1 & 3099.7 & 1809.2 \\
\hline 2371.9 & 2799.8 & 1855.3 & 1771.1 & 2300.6 & 1902.0 & 2770.8 & 1798.2 & 2067.0 & 1570.5 & 3100.2 & 1809.0 \\
\hline 2270.2 & 2800.9 & 1839.9 & 1869.7 & 2300.7 & 1908.6 & 2871.9 & 1799.7 & 2080.1 & 1470.5 & 3099.7 & 1814.1 \\
\hline 2170.1 & 2800.4 & 1837.5 & 1970.7 & 2300.6 & 1923.2 & 2970.9 & 1800.4 & 2077.0 & 1470.4 & 3199.6 & 1781.1 \\
\hline 2069.7 & 2800.2 & 1843.5 & 2070.0 & 2300.3 & 1927.9 & 3069.4 & 1798.9 & 2081.9 & 1569.8 & 3199.9 & 1776.2 \\
\hline 1969.3 & 2800.4 & 1845.7 & 2171.1 & 2300.9 & 1931.5 & 3169.6 & 1799.4 & 2091.6 & 1670.1 & 3199.9 & 1780.4 \\
\hline 1871.2 & 2799.8 & 1847.1 & 2271.1 & 2301.6 & 1941.4 & 3168.3 & 1700.8 & 2120.7 & 1769.7 & 3198.7 & 1790.8 \\
\hline 1771.5 & 2798.8 & 1848.9 & 2370.4 & 2301.1 & 1944.3 & 3070.5 & 1701.5 & 2100.8 & 1870.9 & 3201.1 & 1800.3 \\
\hline 1670.1 & 2798.7 & 1850.7 & 2469.8 & 2300.9 & 1957.6 & 2968.7 & 1699.1 & 2079.9 & 1970.8 & 3200.2 & 1799.1 \\
\hline 1569.7 & 2798.2 & 1851.7 & 2569.6 & 2301.2 & 2005.2 & 2871.4 & 1702.4 & 2077.0 & 2069.2 & 3200.0 & 1779.8 \\
\hline 1472.4 & 2798.7 & 1861.5 & 2472.9 & 2201.2 & 1963.4 & 2770.7 & 1701.2 & 2063.6 & 2170.7 & 3199.8 & 1775.2 \\
\hline 1469.2 & 2700.6 & 1871.7 & 2371.1 & 2200.1 & 1952.2 & 2670.9 & 1700.1 & 2050.0 & 2169.9 & 3299.6 & 1732.5 \\
\hline 1571.6 & 2701.5 & 1859.1 & 2271.0 & 2198.5 & 1949.3 & 2570.1 & 1701.4 & 2035.7 & 2069.0 & 3300.4 & 1737.8 \\
\hline 1671.2 & 2698.9 & 1858.6 & 2171.2 & 2198.7 & 1942.0 & 2469.7 & 1700.1 & 2031.6 & 1970.9 & 3299.8 & 1738.3 \\
\hline 1769.9 & 2701.4 & 1857.5 & 2068.2 & 2200.5 & 1937.5 & 2368.5 & 1700.7 & 2025.4 & 1870.0 & 3300.8 & 1710.4 \\
\hline 1871.8 & 2700.3 & 1852.4 & 1970.0 & 2199.9 & 1930.0 & 2269.7 & 1699.9 & 2014.0 & 1771.0 & 3298.9 & 1740.3 \\
\hline 1969.9 & 2700.3 & 1851.7 & 1869.5 & 2200.7 & 1920.7 & 2171.2 & 1698.8 & 2004.1 & 1669.3 & 3299.3 & 1746.1 \\
\hline 2069.4 & 2700.5 & 1850.0 & 1770.0 & 2200.0 & 1930.4 & 2069.7 & 1701.3 & 1998.0 & 1568.9 & 3301.0 & 1745.6 \\
\hline 2171.2 & 2701.5 & 1848.1 & 1669.3 & 2200.0 & 1930.5 & 1971.0 & 1698.8 & 2007.7 & 1469.3 & 3300.2 & 1753.6 \\
\hline 2271.0 & 2699.5 & 1859.7 & 1768.9 & 2099.9 & 1943.2 & 2071.0 & 1600.6 & 2028.5 & 1571.2 & 3400.8 & 1718.1 \\
\hline 2370.7 & 2701.0 & 1872.8 & 1872.0 & 2099.1 & 1943.0 & 2170.0 & 1601.0 & 2019.4 & 1671.0 & 3398.3 & 1721.4 \\
\hline 2370.9 & 2601.0 & 1902.4 & 1969.5 & 2099.0 & 1942.7 & 2270.6 & 1600.5 & 2022.2 & 1769.7 & 3401.3 & 1706.6 \\
\hline 2271.9 & 2600.6 & 1891.4 & 2070.5 & 2100.8 & 1945.5 & 2370.4 & 1599.4 & 2027.5 & 1870.3 & 3401.5 & 1685.7 \\
\hline 2169.0 & 2600.2 & 1871.6 & 2170.5 & 2098.8 & 1950.2 & 2470.4 & 1599.8 & 2038.3 & 2071.8 & 3400.1 & 1710.6 \\
\hline 2070.1 & 2601.2 & 1862.2 & 2270.9 & 2098.4 & 1953.4 & 2570.9 & 1599.2 & 2045.5 & 1869.2 & 3498.3 & 1660.1 \\
\hline 1969.9 & 2601.0 & 1861.7 & 2569.8 & 2097.9 & 2000.9 & 2670.1 & 1600.3 & 2056.3 & 1770.7 & 3499.9 & 1679.5 \\
\hline 1870.2 & 2599.8 & 1864.6 & 2469.7 & 2101.7 & 1970.8 & 2769.1 & 1601.3 & 2070.3 & 1670.6 & 3499.4 & 1694.0 \\
\hline 1769.7 & 2599.4 & 1867.4 & 2371.8 & 2098.3 & 1958.1 & 2869.6 & 1601.3 & 2081.8 & 1569.9 & 3500.3 & 1679.4 \\
\hline 1671.3 & 2599.0 & 1868.8 & 1871.5 & 2000.1 & 1966.0 & 2972.2 & 1602.7 & 2099.4 & 1669.7 & 3599.2 & 1666.8 \\
\hline 1570.6 & 2601.5 & 1871.0 & 1969.6 & 2000.3 & 1959.6 & 3069.5 & 1602.8 & 2125.1 & 1770.2 & 3601.3 & 1656.1 \\
\hline 1470.7 & 2499.7 & 1898.6 & 2070.4 & 2001.2 & 1959.2 & 2872.6 & 1498.2 & 2100.9 & 1869.7 & 3601.3 & 1644.5 \\
\hline 1571.0 & 2501.2 & 1879.6 & 2169.4 & 2000.5 & 1956.8 & 2770.6 & 1500.6 & 2075.0 & 1671.1 & 3699.1 & 1644.2 \\
\hline 1670.1 & 2500.6 & 1878.8 & & & & & & & & & \\
\hline
\end{tabular}




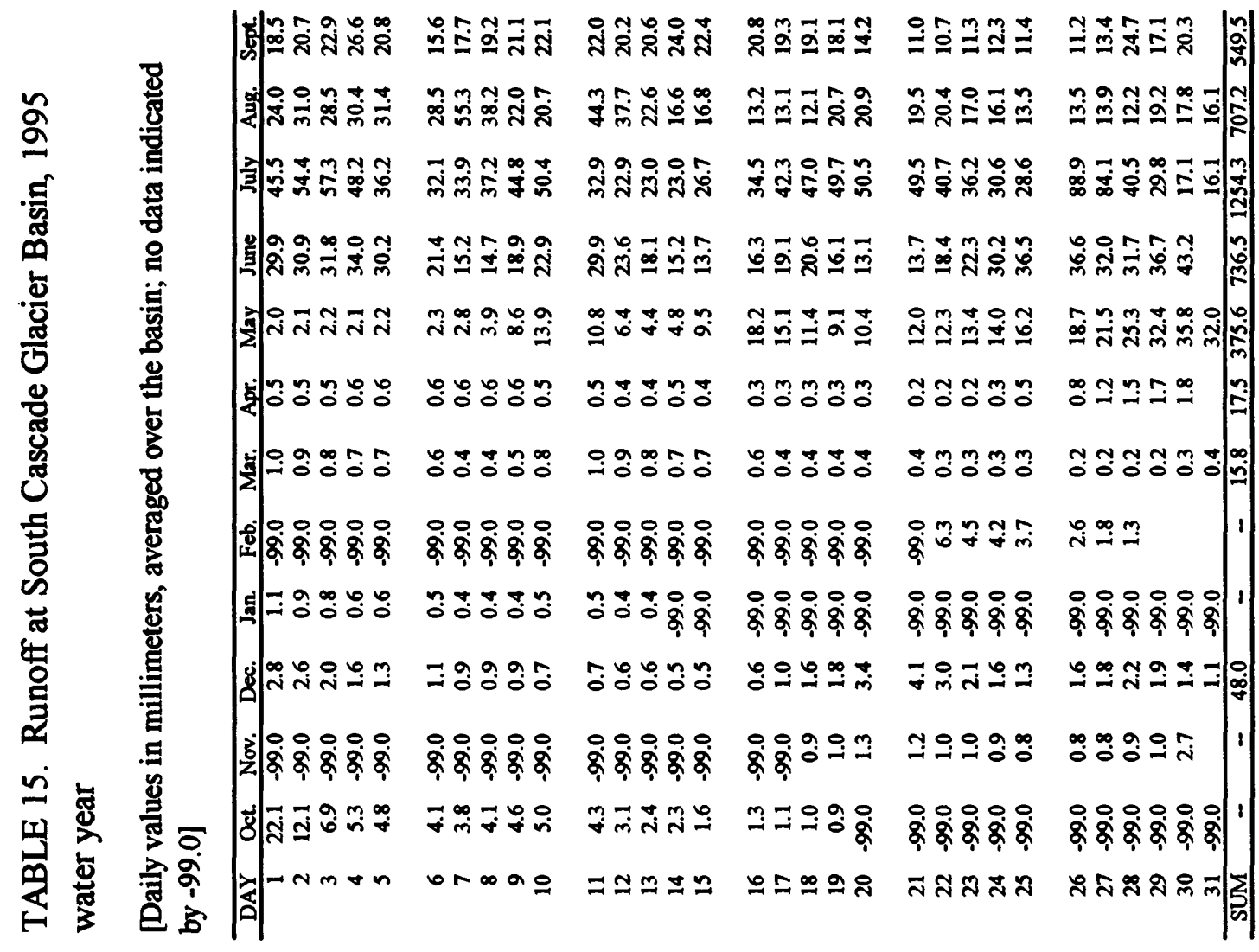

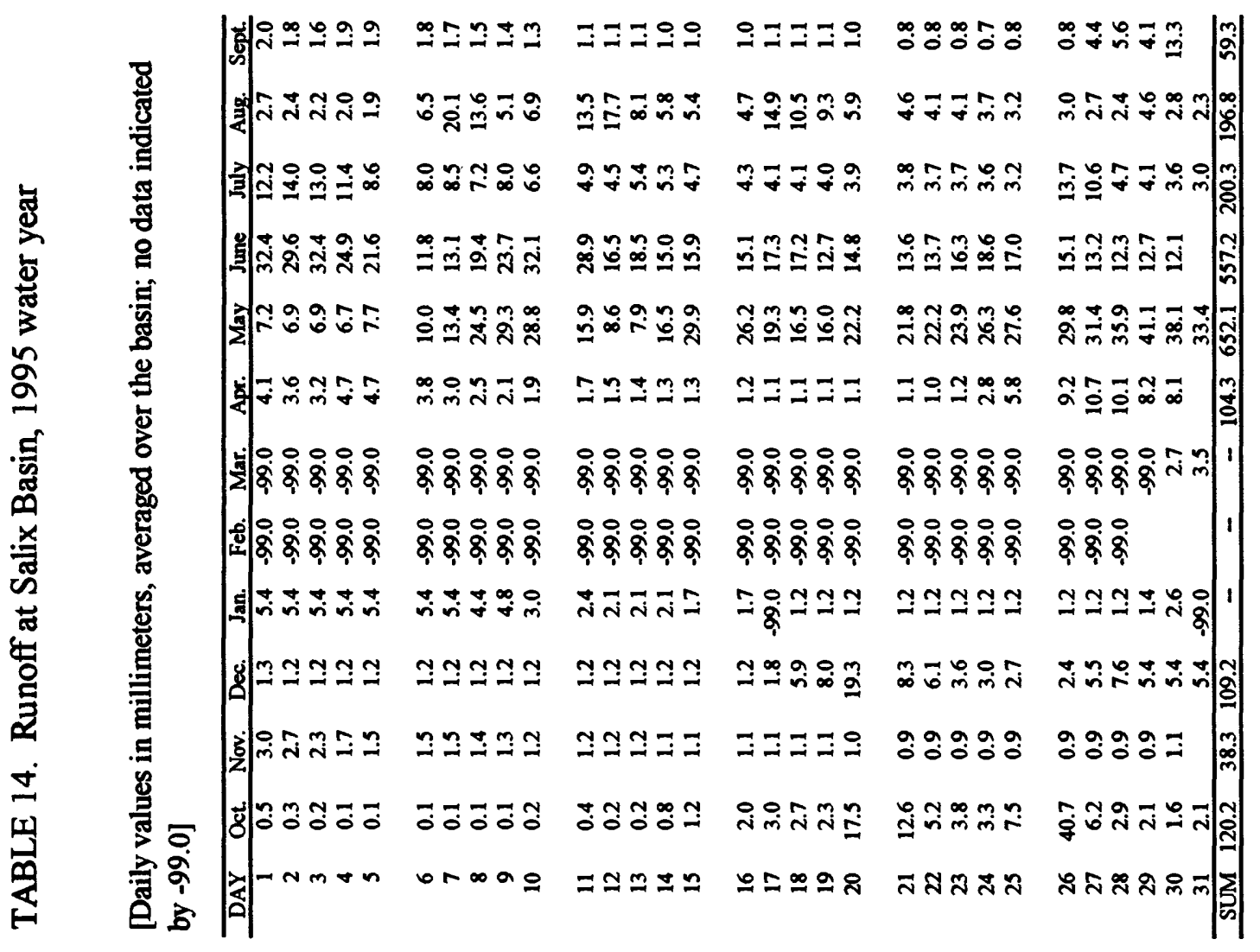


TABLE 16. Runoff at Middle Tarn Basin, 1995 water year

[Daily values in millimeters, averaged over the basin]

\begin{tabular}{|c|c|c|c|c|c|c|c|c|c|c|c|c|}
\hline DAY & Oct. & Nov. & Dec. & Jan. & Feb. & Mar. & Apr. & May & June & July & Aug. & Sept. \\
\hline 1 & 26.7 & 1.6 & 0.2 & 0.2 & 8.6 & 0.3 & 0.2 & 0.8 & 25.0 & 42.4 & 30.2 & 21.6 \\
\hline 2 & 10.0 & 1.2 & 0.2 & 0.2 & 2.8 & 0.3 & 0.2 & 0.8 & 26.1 & 50.0 & 30.5 & 22.1 \\
\hline 3 & 7.8 & 0.9 & 0.2 & 0.2 & 1.4 & 0.3 & 0.2 & 0.8 & 28.0 & 48.1 & 29.5 & 26.1 \\
\hline 4 & 7.7 & 3.3 & 0.2 & 0.2 & 1.2 & 0.3 & 0.2 & 0.8 & 27.7 & 39.4 & 33.2 & 27.0 \\
\hline 5 & 6.5 & 1.6 & 0.2 & 0.2 & 1.1 & 0.3 & 0.2 & 0.9 & 23.9 & 30.7 & 28.2 & 18.1 \\
\hline 6 & 5.6 & 0.9 & 0.2 & 0.2 & 1.1 & 0.3 & 0.2 & 1.4 & 16.3 & 29.8 & 31.5 & 16.6 \\
\hline 7 & 6.7 & 0.8 & 0.2 & 0.2 & 0.9 & 0.3 & 0.2 & 2.7 & 12.8 & 33.3 & 48.6 & 20.2 \\
\hline 8 & 7.3 & 0.9 & 0.2 & 0.2 & 0.6 & 0.3 & 0.2 & 4.9 & 13.8 & 33.6 & 26.9 & 21.8 \\
\hline 9 & 8.1 & 1.2 & 0.2 & 0.2 & 0.4 & 0.3 & 0.2 & 8.6 & 17.3 & 47.6 & 18.9 & 22.0 \\
\hline 10 & 7.4 & 0.5 & 0.2 & 0.2 & 0.2 & 0.3 & 0.2 & 11.8 & 20.7 & 40.3 & 25.2 & 24.1 \\
\hline 11 & 5.7 & 0.5 & 0.2 & 0.2 & 0.2 & 0.3 & 0.2 & 7.2 & 23.6 & 25.5 & 42.1 & 21.2 \\
\hline 12 & 3.9 & 0.6 & 0.2 & 0.2 & 0.3 & 0.3 & 0.2 & 4.9 & 17.9 & 21.4 & 28.8 & 19.5 \\
\hline 13 & 2.7 & 0.4 & 0.2 & 0.2 & 0.3 & 0.2 & 0.2 & 4.3 & 15.1 & 22.7 & 17.8 & 26.3 \\
\hline 14 & 2.3 & 0.5 & 0.2 & 0.2 & 0.3 & 0.2 & 0.2 & 6.1 & 12.9 & 24.1 & 15.5 & 27.1 \\
\hline 15 & 1.8 & 0.5 & 0.2 & 0.2 & 0.3 & 0.2 & 0.2 & 10.4 & 13.6 & 29.8 & 18.1 & 22.7 \\
\hline 16 & 1.7 & 0.7 & 0.2 & 0.2 & 0.3 & 0.2 & 0.2 & 12.8 & 16.9 & 37.2 & 12.6 & 21.8 \\
\hline 17 & 1.9 & 0.4 & 0.2 & 0.2 & 0.3 & 0.2 & 0.2 & 11.4 & 18.9 & 43.2 & 12.0 & 18.8 \\
\hline 18 & 1.9 & 0.3 & 0.5 & 0.2 & 0.3 & 0.2 & 0.2 & 9.3 & 17.5 & 46.2 & 11.3 & 19.9 \\
\hline 19 & 1.7 & 0.8 & 0.4 & 0.2 & 0.3 & 0.2 & 0.2 & 8.4 & 12.6 & 49.2 & 24.9 & 16.2 \\
\hline 20 & 2.5 & 1.1 & 1.7 & 0.2 & 0.3 & 0.2 & 0.2 & 9.9 & 11.7 & 49.1 & 19.9 & 12.6 \\
\hline 21 & 2.5 & 0.6 & 1.1 & 0.2 & 0.3 & 0.2 & 0.2 & 10.3 & 14.4 & 43.8 & 22.3 & 12.2 \\
\hline 22 & 1.4 & 0.3 & 0.4 & 0.2 & 0.3 & 0.2 & 0.2 & 10.8 & 19.7 & 37.9 & 19.5 & 11.9 \\
\hline 23 & 1.3 & 0.2 & 0.2 & 0.2 & 0.3 & 0.2 & 0.2 & 11.4 & 22.9 & 33.0 & 16.5 & 13.6 \\
\hline 24 & 1.3 & 0.2 & 0.2 & 0.2 & 0.3 & 0.2 & 0.2 & 12.3 & 29.9 & 28.8 & 15.2 & 13.4 \\
\hline 25 & 1.6 & 0.2 & 0.2 & 0.2 & 0.3 & 0.2 & 0.2 & 14.2 & 33.9 & 32.6 & 13.4 & 10.6 \\
\hline 26 & 12.4 & 0.2 & 0.2 & 0.2 & 0.3 & 0.2 & 0.3 & 16.1 & 31.5 & 94.1 & 14.0 & 11.4 \\
\hline 27 & 4.1 & 0.2 & 0.3 & 0.2 & 0.3 & 0.2 & 0.6 & 17.9 & 29.8 & 59.5 & 13.4 & 17.8 \\
\hline 28 & 2.7 & 0.2 & 0.5 & 0.2 & 0.3 & 0.2 & 0.7 & 21.6 & 31.3 & 31.9 & 14.7 & 25.0 \\
\hline 29 & 2.0 & 0.2 & 0.3 & 0.2 & & 0.2 & 0.6 & 27.2 & 37.6 & 23.2 & 24.1 & 13.2 \\
\hline 30 & 1.7 & 0.3 & 0.2 & 0.3 & & 0.2 & 0.7 & 26.9 & 40.3 & 15.1 & 16.9 & 21.6 \\
\hline 31 & 1.8 & & 0.2 & 4.9 & & 0.2 & & 25.0 & & 20.0 & 17.8 & \\
\hline SUM & 152.5 & 21.0 & 9.3 & 10.5 & 23.6 & 7.5 & 7.4 & 311.7 & 663.6 & 1163.7 & 693.5 & 576.4 \\
\hline
\end{tabular}


TABLE 17. Values used to interpolate density at any altitude (in meters)

\begin{tabular}{cc}
\hline Altitude & Density \\
\hline 1594 & 0.490 \\
1615 & 0.500 \\
1684 & 0.510 \\
1740 & 0.515 \\
1825 & 0.520 \\
1880 & 0.522 \\
1980 & 0.524 \\
2200 & 0.525 \\
\hline
\end{tabular}

TABLE 18. Values used to interpolate snow depth (in meters) at any altitude (in meters)

\begin{tabular}{cc}
\hline Altitude & Snow Depth \\
\hline 1615 & 1.0 \\
1637 & 2.0 \\
1670 & 3.0 \\
1733 & 4.0 \\
1820 & 5.0 \\
1988 & 6.0 \\
2115 & 6.5 \\
2270 & 7.0 \\
\hline
\end{tabular}




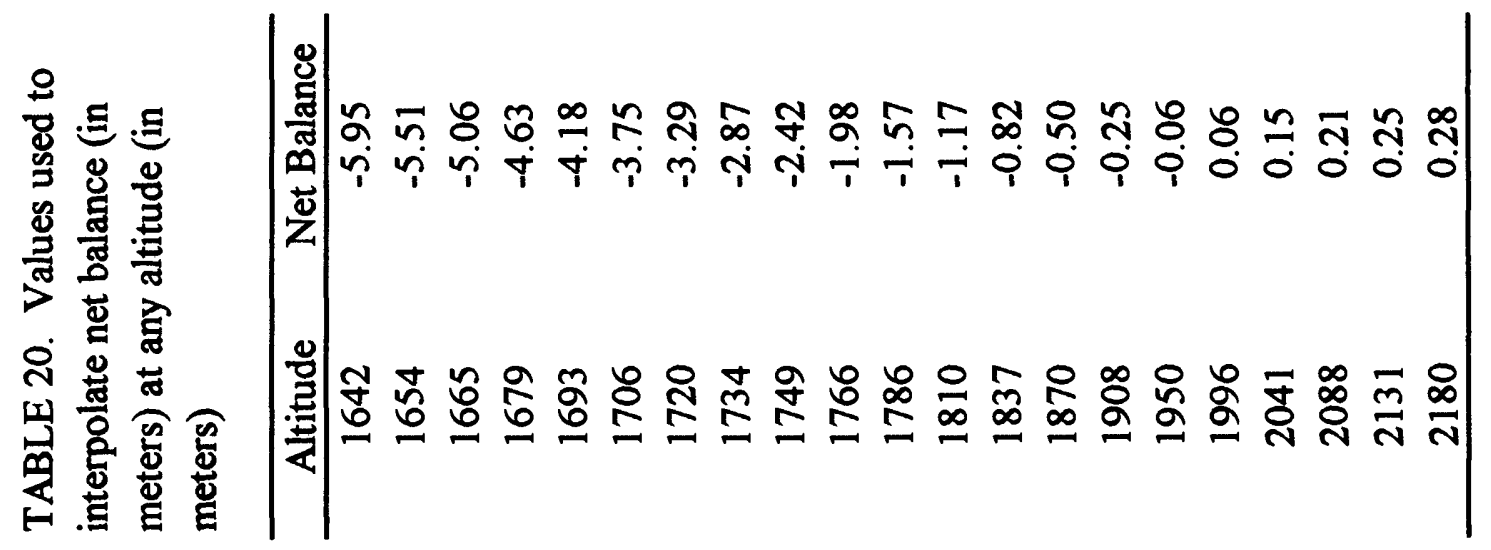

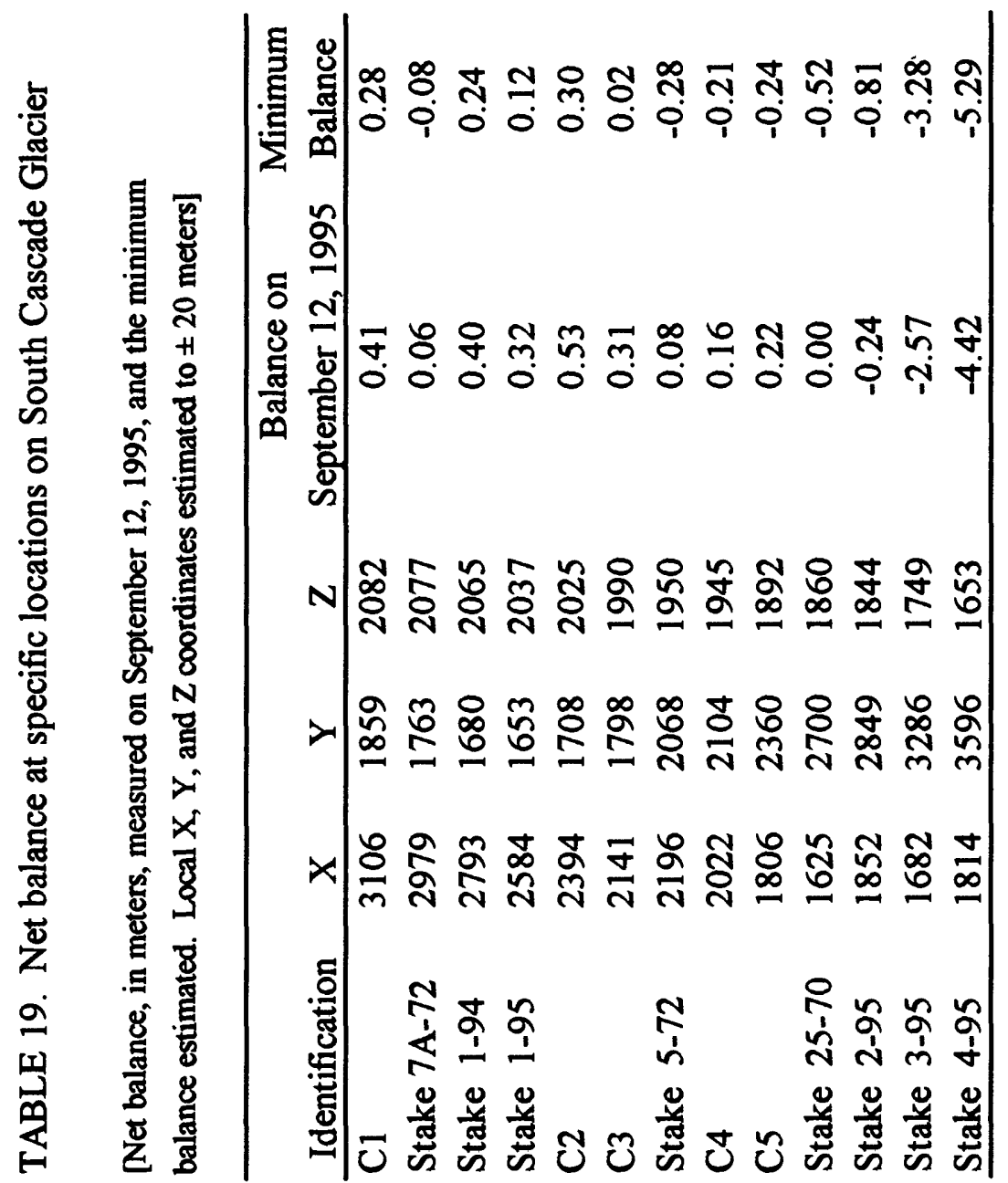

